\title{
过渡金属催化不对称氧化反应方法研究进展
}

\author{
姚彪巫佳浩汪钰江焕峰* \\ (华南理工大学化学与化工学院 广东省功能分子工程重点实验室 广州 510641)
}

\begin{abstract}
摘要 过渡金属催化的不对称氧化反应, 作为不对称合成的重要研究内容之一, 为手性天然产物和药物的合成提供了 实用便捷途径，因此其方法研究备受人们关注. 重点介绍了近年来过渡金属催化的烯烃不对称氧化官能团化反应、 C$\mathrm{H}$ 键不对称氧化反应、不对称 BV 氧化反应和硫醚不对称氧化反应等研究进展，并展望其未来发展趋势.

关键词＼cjkstart过渡金属催化; 不对称氧化; 对映选择性; 烯烃; 碳-氢活化
\end{abstract}

\section{Methods of Transition Metal-Catalyzed Asymmetric Oxidation}

\author{
Yao, Biao Wu, Jiahao Wang, Yu Jiang, Huanfeng* \\ (Key Laboratory of Functional Molecular Engineering of Guangdong Province, School of Chemistry and \\ Chemical Engineering, South China University of Technology, Guangzhou 510641)
}

\begin{abstract}
Transition metal-catalyzed asymmetric oxidation, as one of important research targets of chiral synthesis, provides a direct, practical route for the synthesis of various chiral bioactive products and drugs, and has received much attention. The recent progress of the methods of transition metal-catalyzed asymmetric oxidation, especially, asymmetric oxidative functionalization of olefins, $\mathrm{C}-\mathrm{H}$ bond asymmetric oxidation reaction, asymmetric BV oxidation and sulfide asymmetric oxidation is elaborated. Outlook of those issuesis is also discussed.
\end{abstract}

Keywords transition metal catalysis; asymmetric oxidation; enantioselectivity; olefin; $\mathrm{C}-\mathrm{H}$ activation

不对称氧化反应(Asymmetric oxidation reaction)是 指有机化合物分子在引入电负性原子过程中产生手性 中心的一类反应，是不对称合成的重要分支之一. 在催 化剂和氧化剂参与下, 底物分子氧化数升高, 通常表现 为脱氢或者杂原子官能团的定向引入, 实现底物分子的 不对称性官能团富集化过程, 为手性分子合成提供最直 接的途径, 在天然产物和药物分子的合成方面显得尤为 重要 ${ }^{[1]}$.

在不对称氧化反应中，对映选择性控制是难点之 一，而过渡金属与配体的协同作用为难点的解决提供了 一种有效途径. 过渡金属和配体的协同作用过程中, 金 属促使反应发生, 而配体决定产物的对映选择性. 例如 Sharpless 报道的催化剂——钛和酒石酸的络合物在实 现烯丙醇类化合物的不对称环氧化反应中, 配体酒石酸 的构型改变氧原子的进攻方向, 调控产物的空间构型 ${ }^{[2]}$. 烯烃的不对称氧化反应 ${ }^{[3-4]}$ 的实现, 为不对称合成开辟
出一条新路径, 为精准合成提供更多可能的策略. 该方 法的成功报道, 促进了该领域的发展. 人们不断开发新 的配体和中心过渡金属的种类, 发展新型不对称氧化反 应, 引入光化学等途径在更深层次研究不对称氧化过 程，从而促使不对称氧化反应朝着更加高效和更好对映 选择性的方向发展，形成具有绿色、精准、实用等特征 的不对称氧化反应合成方法学研究体系.

本文将重点介绍近年来利用热化学或者光化学的 过渡金属介入的不对称氧化反应及其合成方法学研究, 包括过渡金属参与的烯烃不对称环氧化反应、 $\mathrm{C}-\mathrm{H}$ 键 不对称氧化反应、不对称 BV 氧化反应和硫醚不对称氧 化反应等几个方面.

\section{1 过渡金属参与的烯烃不对称氧化反应}

烯烃是重要的大宗基础化工原料, 其不对称氧化产 物作为化学工业、材料工业和制药工业的重要前体，是

* Corresponding author. E-mail: jianghf@scut.edu.cn

Received May 31, 2020; revised July 6, 2020; published online August 11, 2020

Dedicated to Professor Henry N. C. Wong on the occasion of his 70th birthday.

Project supported by the National Key Research and Development Program of China (No. 2016YFA06002900) and the Key Research and Development Program of Guangdong Province (No. 2020B010188001)

国家重点研发计划(No. 2016YFA06002900)和广东省重点领域研发(No. 2020B010188001)资助项目. 
现代合成工业不可或缺的物质基础. 本部分将主要介绍 过渡金属参与的烯烃不对称氧化反应，包括烯烃的不对 称氧化 Heck 反应、不对称 Wacker 氧化反应、不对称双 官能团化反应及不对称环氧化反应等.

\section{1 烯烃的不对称环氧化反应}

烯烃分为官能团化和非官能团化烯烃, 在官能团化 烯烃的对映选择性的环氧化过程中, 官能团发挥着重要 的作用，它与催化剂形成中间体，控制反应的发生和产 物的对映选择性. 2016 年, 何炜等 ${ }^{[5]}$ 报道了烯基磺酰胺 的不对称环氧化反应, 反应中底物烯基磺酰胺 $\mathbf{1}$ 与 $\mathrm{Ti}$ 和 配体 2 络合形成中间体 $\mathbf{4}$, 是该反应产物对映选择性的决 定步. 通过钛络合物催化剂与底物官能团形成中间体实 现手性中心的构筑, 证明了催化剂与底物官能团作用这 种因素在手性中心构筑过程中的重要作用(Scheme 1).

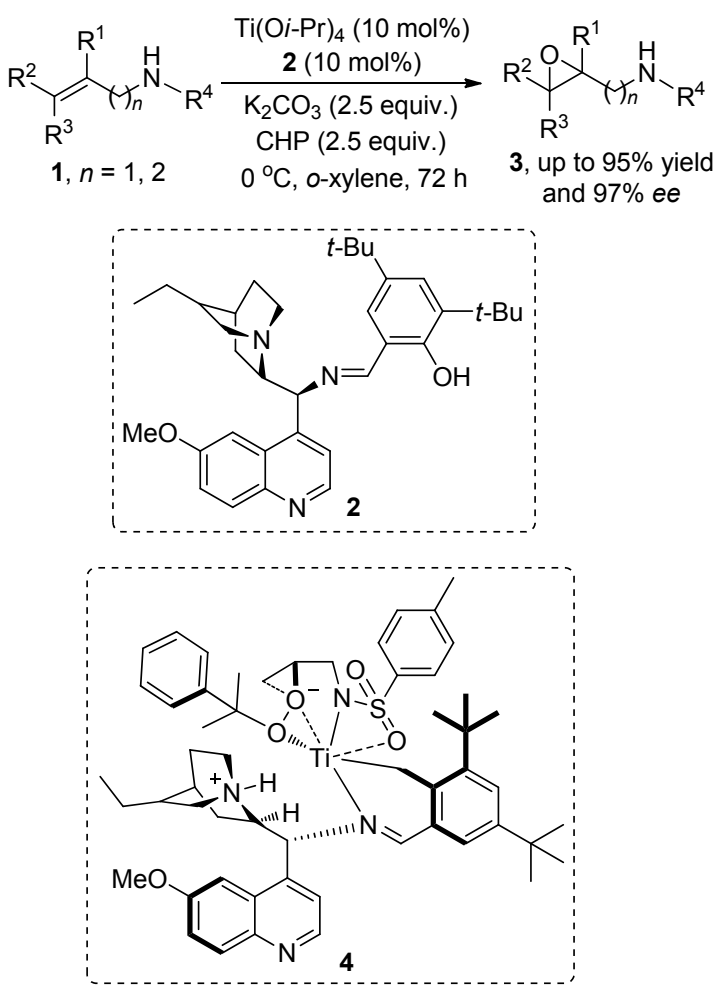

图式 $1 \mathrm{Ti}$ 催化烯基酰胺的不对称环氧化反应

Scheme 1 Ti-catalyzed asymmetric epoxidation of enamide

2014 年, Yamamoto 等 ${ }^{[6]}$ 报道了多取代烯基醇类化 合物 5 和配体 6 的不对称环氧化反应, 反应中金属铇和 配体 6 的作用经过了与催化模型 4 类似的过程, 不同的 是该方法中不涉及 $\mathrm{R}^{4}$ 基团的络合作用. 值得注意的是, 该方法使用双氧水为氧化剂, 室温条件下仅 $3 \mathrm{~h}$ 就能高 效得到环氧化产物(最高达 96\%产率和 98\% ee) (Scheme 2). 该方法是通过中心金属与底物的氧原子和氧化剂中 氧原子的孤电子对络合形成中间体, 该中间体的空间取 向决定着氧原子插入双键的方向, 从而实现产物的对映
选择性. 由上述研究报道可知，酰胺基或者羟基与烯基 双键间隔一个或者两个碳原子的底物均可以得到对应 的环氧化产物，两者之间的空间距离对反应的进行和产 物对映选择性较大的影响, 这在 Yamamoto 等 ${ }^{[7]}$ 报道的 钛酸酯与轴手性配体催化的这类反应中，得到了很好的 证实. 多烯基醇或者烯基取代苯酚中双键的环氧化反应 取决于着基的位置，随着双键与着基或者酚羟基距离延 长, 环氧化产物消失, 很好地证明了羟基与作用部分的 距离在反应中的作用(Scheme 3).
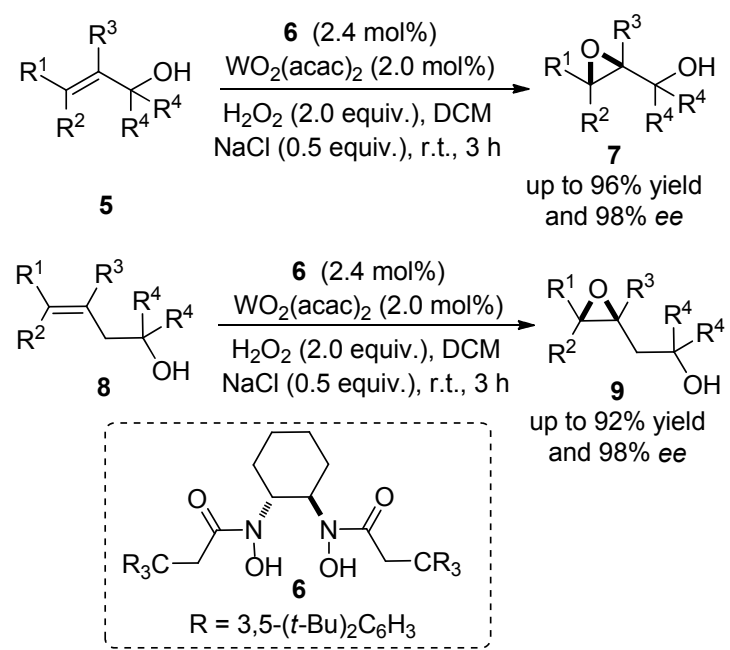

图式 $2 \mathrm{~W}$ 催化的烯基醇类化合物的不对称氧化反应 Scheme 2 W-catalyzed asymmetric oxidation of enol compounds
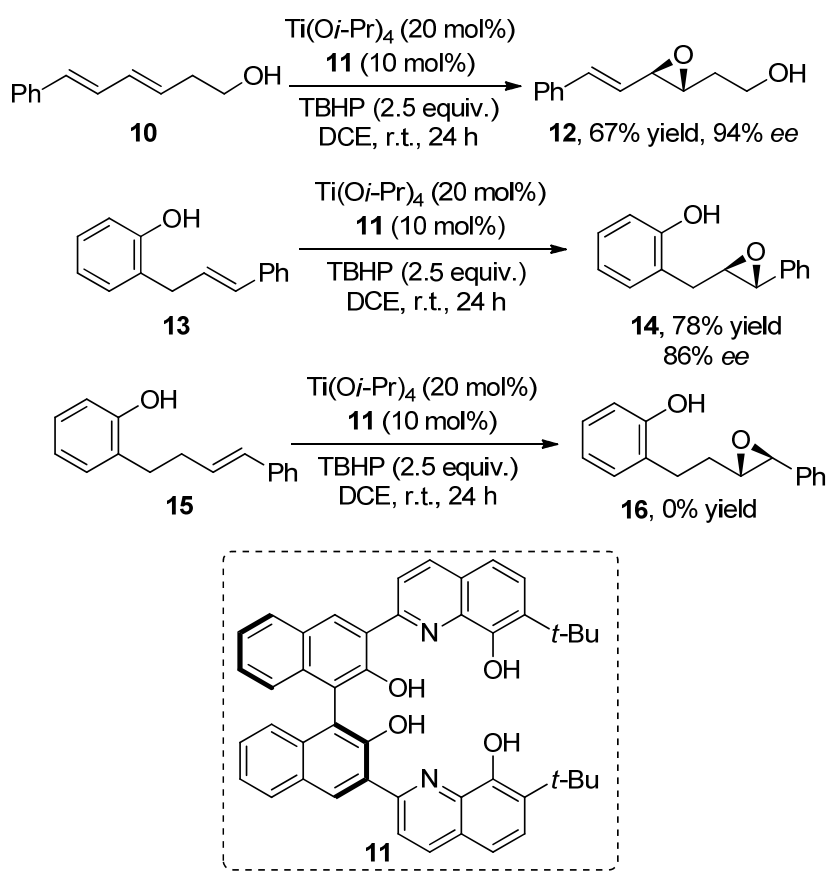

图式 $3 \mathrm{Ti}$ 催化的烯基醇类化合物的不对称氧化反应

Scheme 3 Ti-catalyzed asymmetric oxidation of enol compounds

官能团化烯烃的不对称环氧化反应的成功实现，促 
进了此类烯烃底物的应用，一系列合成方法得以发展 ${ }^{[1]}$. 近几年, 冯小明课题组 ${ }^{[8]}$ 利用自己课题发展的手性氮氧 配体, 制备了一系列手性 $N, N^{\prime}$-二氧化物-Sc(III)催化剂, 实现了 $\alpha, \beta$-不饱和羰基化合物 $\mathbf{1 7}$ 或者 $\mathbf{2 0}$ 的不对称环氧 化反应. 在作者提出的催化模型中, Sc 分别和配体、底 物中羰基的氧原子络合, 在氧化剂的氧原子与中心金属 键合作用下, 完成了对映选择性的环氧化过程. 该方法 对于 $\alpha, \beta$-不饱和单羰基或者双耑基化合物的不对称环氧 化反应, 均得到了很好的反应结果. 底物拓展实验中, 化合物 17 中的 $\mathrm{R}^{1}$ 可以拓展为强吸电子基团(酯基、三氟 甲基和三氯甲基)或者大空间位阻基团, 其中三氟甲基 (或者三氯甲基)具有较大的药物应用意义, 利用化合物 20 的 $\alpha$-双羰基官能团特性, 可以进一步拓展其官能团 化反应(Scheme 4).

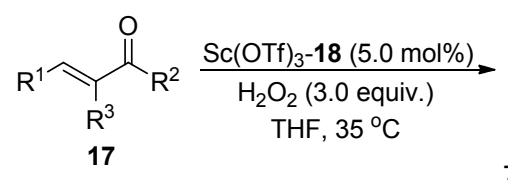
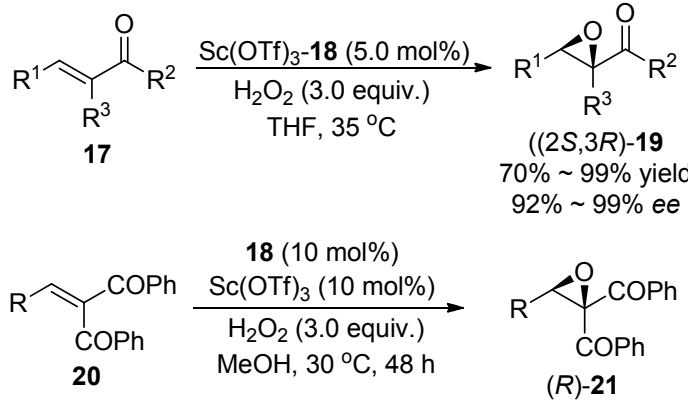

up to $85 \%$ yield and $99 \%$ ee

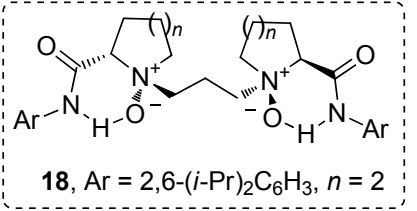

图式 $4 \mathrm{Sc}$ 催化的 $\alpha, \beta$-不饱和羰基化合物不对称环氧化反应 Scheme 4 Sc-catalyzed asymmetric epoxidation of $\alpha, \beta$-unsaturated carbonyl compounds

在冯小明课题组 ${ }^{[8]}$ 和何炜课题组 ${ }^{[5]}$ 的研究工作中, 羰基氧原子和胺基氮原子的配位作用是产物对映选择 性的决定性因素，同时此类基团也影响着反应的效果. 2019 年, Clarasó 等 ${ }^{[9]}$ 利用 $\mathrm{Mn}$ (Salan)催化剂 23 和氧化剂, 实现了 $\beta, \beta$-二取代酰胺 $\mathbf{2 2}$ 的对映选择性环氧化反应, 将 胺基换成酯基，产物的选择性和收率明显下降，证明了 胺基对实现高对映选择性的重要性(Scheme 5).

非官能团化的烯烃不对称环氧化反应的难点在于 中间体空间取向的控制, Mn(Salen)催化剂在非官能团化 烯的不对称环氧化反应中的应用很好地解决了这个的 问题，但是反应对于烯烃的不同构型也存在着差异. 如 顺式(反式)构型烯烃在 $\mathrm{Mn}$ (Salen)催化剂的作用下，得 到的环氧化产物的对映选择性较好, 但反式(顺式)的烯 烃在同等反应条件下其环氧化对映选择性一般，导致这

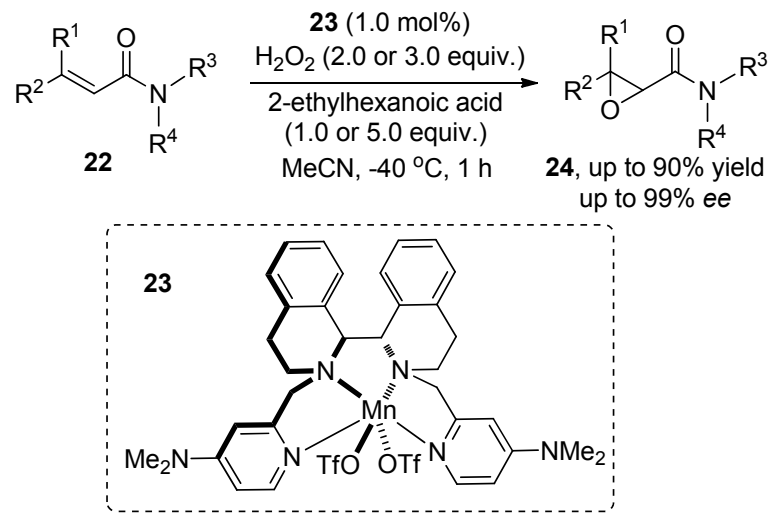

图式 $5 \beta, \beta$-二取代的酰胺不对称环氧化反应

Scheme 5 Asymmetric epoxidation of $\beta, \beta$-disubstituted amide

种现象的原因是烯烃取代基之一与 Salen 配体相互作用, 使氧进入烯烃的所需取向不稳定造成的 ${ }^{[10]}$. 在 Koya 等 ${ }^{[11]}$ 报道中, 利用 $\mathrm{Ru}(\mathrm{Salen})$ 配合物 $\mathbf{2 6}$ 作为催化剂，实 现了芳基烯烃 25 的高对映选择性环氧化反应，顺式和 反式烯烃均能得到目标产物，但是受取代基的影响比较 大. 随着 $\mathrm{R}^{2}$ 和 $\mathrm{R}^{3}$ 的碳链延长，反应产率均明显降低，且 顺式烯烃的对映选择性更好; 在三取代的烯烃的反应 中, $\mathrm{R}^{1}$ 基团引入取代基有利于反应的发生(Scheme 6).
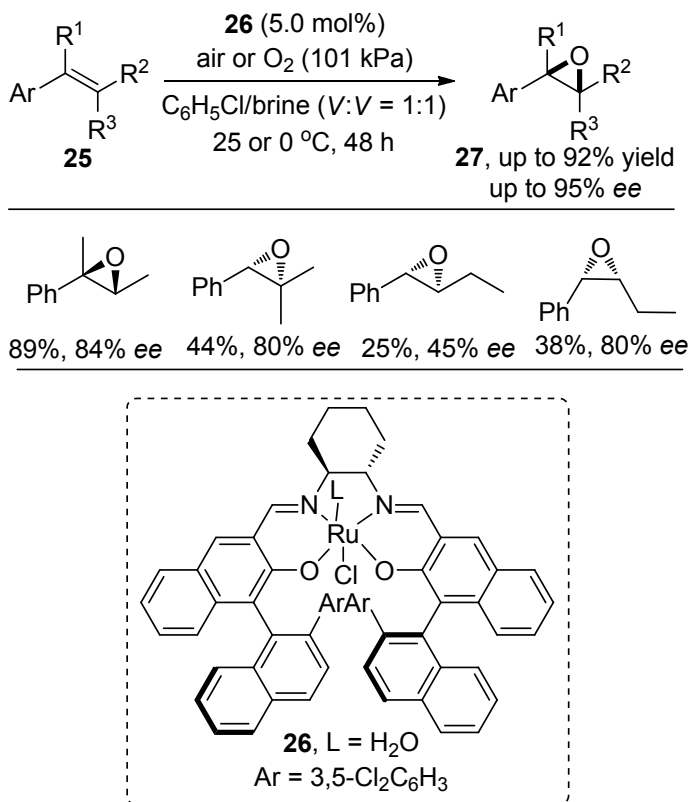

图式 6 钉催化芳基烯烃的不对称氧化反应

Scheme 6 Ru-catalyzed asymmetric oxidation of aryl olefins

在三取代烯烃的反应中，受取代基的影响，实现其 环氧化产物的对映选择性存在较大限制. Kobayashi 等 ${ }^{[12]}$ 利用以三价 $\mathrm{Fe}$ 作为中心金属、手性 Salen 为配体的 络合物 29 实现了烯烃 28 的不对称环氧化反应. 在该 $\mathrm{Fe}$ (Salen)催化体系中，通过改变手性配体的骨架，得到 了单一构型的对映体，整个反应对 $E$ 式的烯烃表现出更 
好的对映选择性. 而 Farokhi 等 ${ }^{[13]}$ 报道的 Mn 卟啉催化 剂 33 在芳基烯烃 32 的环氧化反应上表现出了极高的对 映选择性(最高>99\%ee)(Scheme 7).

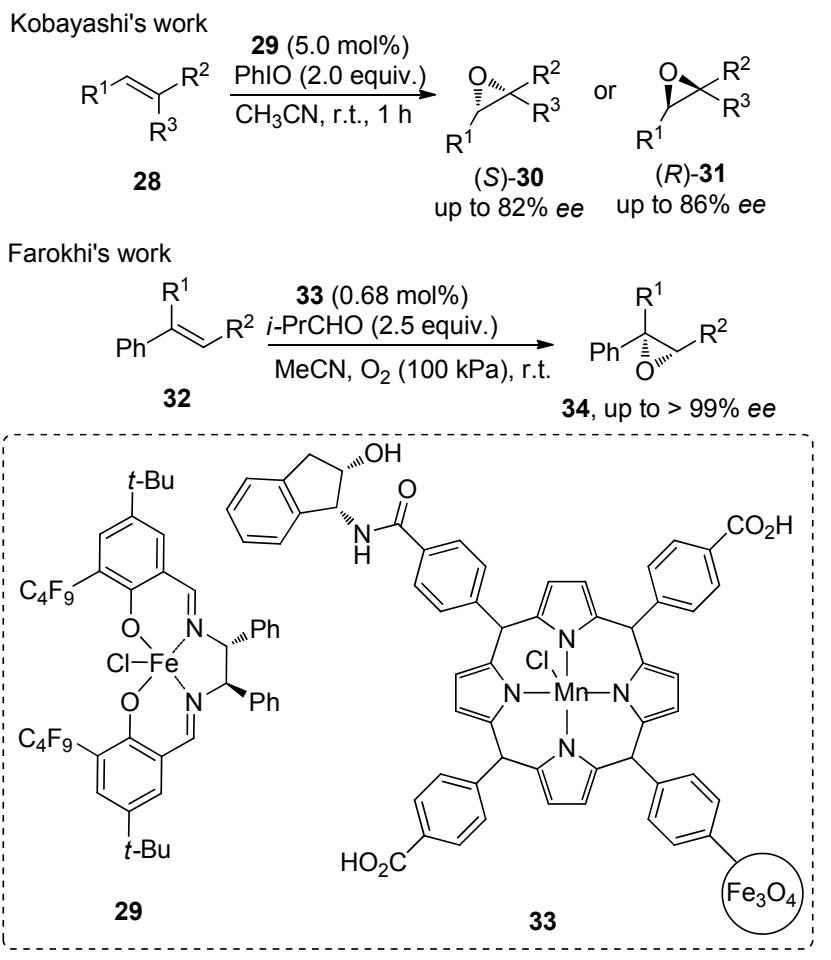

图式 7 三取代烯烃的不对称氧化反应

Scheme 7 Asymmetric oxidation of tri-substituted olefins

共轭烯烃的环氧化反应一般是单个双键被氧化, 反 应位点取决于双键的空间位阻效应，空间位阻较小的优 先反应. 如 Jat 等 ${ }^{[14]}$ 在钛和 Salan 36 的络合物催化剂和 双氧水氧化剂作用下, 实现了共轭二烯 35 的选择性单 环氧化反应. 反应中, 位阻较小的碳碳双键优先反应. 在底物实验中, 发现通过改变配体 $\mathbf{3 6}$ 的构型, 可以高对 映选择性地得到单一构型的非对映异构体, 这也表明底 物原手性中心对产物最终构型没有影响(Scheme 8).

由此可见, 在官能团化烯烃中, 反应中催化剂与官 能团络合形成中间体，控制氧原子的进攻方向从而控制 其产物的手性; 而在非官能团烯烃中, 最为常见的是催 化剂与底物 $\pi$ 键络合, 形成具有一定空间取向的中间体, 从而控制氧原子的进攻方向. 在已有的报道中, 取代基 团的空间效应对反应有比较大的影响，通过取代基团的 修饰可以改善不对称氧化反应的选择性, 并将反应拓展 到多取代烯烃底物.

\section{2 烯烃不对称双官能化反应}

烯烃不对称双差基化和羟胺化反应推进了烯烃氧 化双官能化反应的应用 ${ }^{[4]}$, 近年来, 过渡金属催化体系 的不断开发, 促进了不对称氧化双官能化的极大发展.
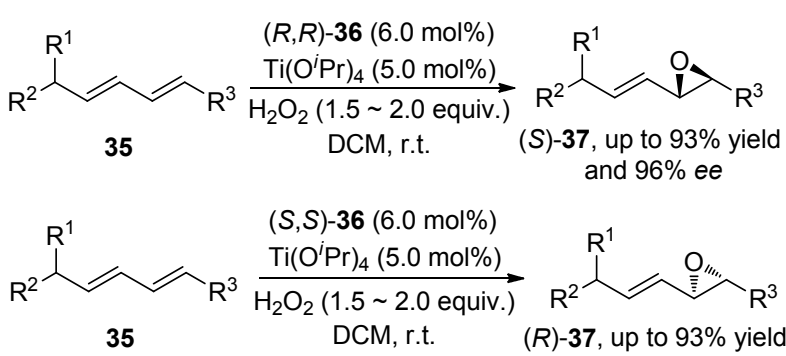
and $96 \%$ ee

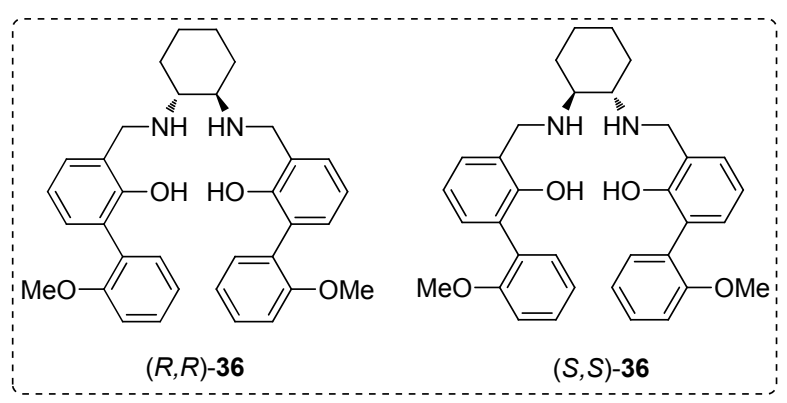

图式 8 钛催化的共轭二烯不对称氧化反应

Scheme 8 Ti-catalyzed asymmetric oxidation of conjugated dienes

在烯烃的不对称环氧化反应中，官能团化的烯烃易 于发生此类反应，官能团的存在不仅会影响烯烃中双键 的活性，也会在与催化剂作用时控制产物的手性，这种 影响因素在烯烃的不对称氧化双官能团化反应中也同 样存在. 2014 年, 刘国生课题组 ${ }^{[15]}$ 报道了烯醇类化合物 38 的分子内氧化胺化反应. 该反应借助钯催化剂与底 物官能团的作用, 在氧化剂的作用下, 以高的产率和对 映选择性得到多种烷基醇. 该反应中, 首先钯催化剂与 $\mathrm{N}$ 原子以及双键络合，随后进行迁移插入形成烷基钯， 烷基钯物种经过一步氧化后变成四价钯, 最后经历 $\mathrm{H}_{2} \mathrm{O}_{2}$ 对烷基 $\mathrm{C}-\mathrm{Pd}$ 键的氧化裂解, $\mathrm{H}_{2} \mathrm{O}$ 对氧化裂解的碳 进行亲核进攻得到目标产物. 值得注意的是 $\mathrm{R}$ 基团是构 筑产物手性中心的重要因素, 产物的非对映选择性是通 过反应中环状中间体直接形成的，并未涉及外加手性诱 导因素，去掉 $\mathrm{R}$ 基团非对映选择性就不能实现. 随后， 他们 ${ }^{[16]}$ 将反应拓展到烷基烯胺 $\mathbf{4 0}$ 的分子内不对称氧化 胺化反应，该反应在钯络合物催化剂和氧化剂作用下， 得到了很好的反应结果， $\mathrm{R}$ 基团空间位阻效应可以控制 产物中环的大小, 但是对产物的映选择性影响不大 (Scheme 9).

Chemler 等 ${ }^{[17]}$ 首次报道了胺铜化、氧铜化启动的烯 烃不对称氧化双官能团化反应. 该方法的发现促进了金 属参与的烯烃双官能化不对称氧化反应的研究. 2015 年, 曾伟课题组 ${ }^{[18]}$ 利用铜和二氧化锰的氧化体系实现 了烯烃 43 的分子内不对称双胺化反应, 产物 $e e$ 值高达 $95 \%$ 以上. 反应涉及铜的迁移插入和碳铜键均裂，最后 经过高价铜的还原消除得到产物, 该方法为手性单环二 
2014<smiles>[R]C(C=C)OC(=O)N[AsH3-]</smiles>

38

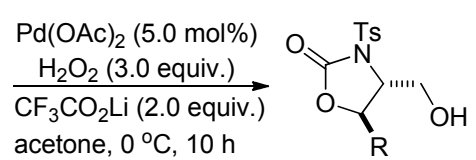

39 , up to $95 \%$ yield and $>20: 1 d r$
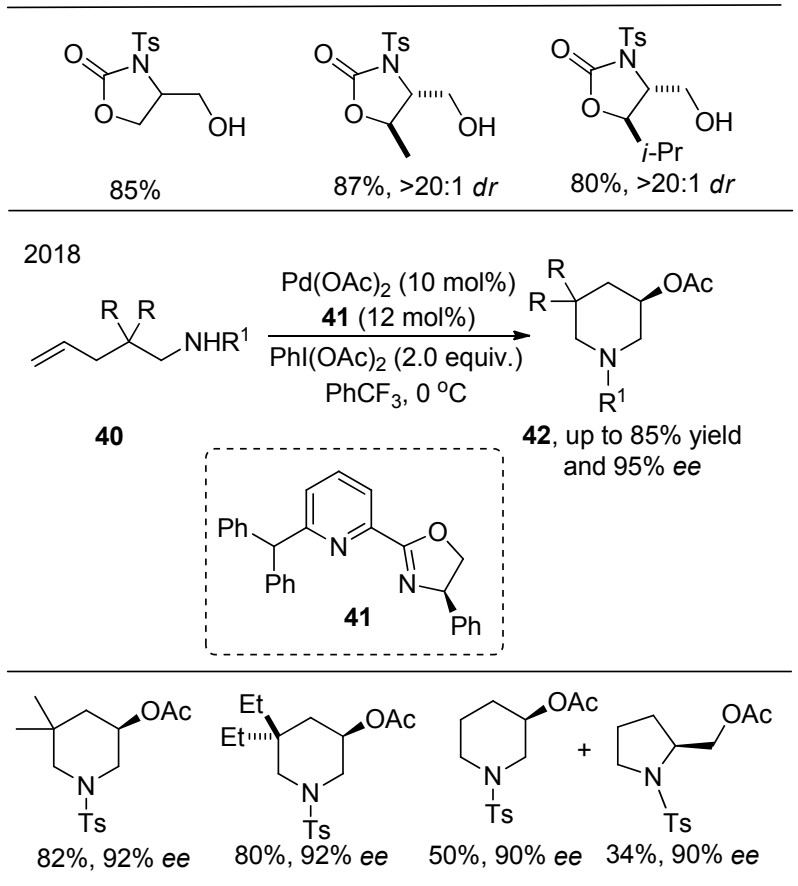

图式 9 烯烃分子内不对称氧化胺化反应

Scheme 9 Asymmetric oxidative amination of olefins

胺 45 的合成提供了一个有效的途径. 2017 年, 刘国生课 题组 ${ }^{[19]}$ 在烯烃分子内不对称氧化胺化反应的研究基础 上, 发展了钯和手性配体喹啉-噁唑啉 47 催化体系, 在 氧化剂 $\mathrm{Ag}_{2} \mathrm{CO}_{3}$ 的作用下, 烯烃 46 发生分子内不对称环 氧化胺化反应, 得到了多种二氢吲哚 $\mathbf{4 8}$, 反应具有高产 率和优异的对映选择性. 酮酸在反应过程中与催化剂络 合参与反应, 故而酮酸的加入可加速反应和提高产物对 映选择性, 不足的是反应时间较长(基本都在 $72 \mathrm{~h}$ 左右). 烯烃的官能团可以参与反应构建新化学键, 也可以仅作 为辅助基团以活化特定位置的化学键. 如在陈弓和何刚 课题组 ${ }^{[20]}$ 报道的烯烃双官能化反应中, 辅助基团喹啉 是构筑其分子内叔碳和季碳中心的对映选择性的关键, 但不参与产物的成键. 该方法以钯和手性配体 $\mathbf{5 0}$ 的络 合物为催化剂, 在氧化剂的作用下, 可以得到较高的反 应产率和对映选择性. 在作者给出的机理中, 钯催化剂 与底物形成络合物, 随后进行迁移插入形成烷基钯中间 体, 接着中间体与硼酸进行转金属化反应, 最后还原消 除得到产物 51. 底物实验中, 在众多亲核反应底物中, $N$-酰亚胺类底物在该反应中有高的收率和对映选择性 (Scheme 10).
Zeng's work

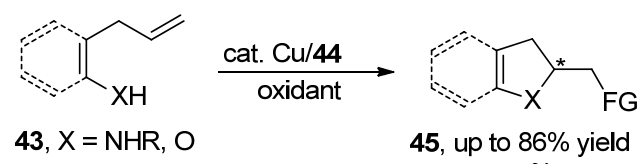
and $98 \%$ ee

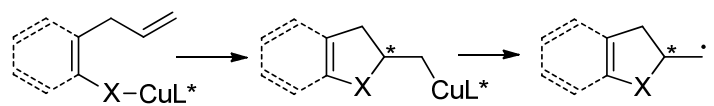<smiles>[X]c1ccc(CC)cc1CCCO</smiles>

Liu's work<smiles>[R]C(=C)c1ccccc1C(=O)Nc1ccccc1F</smiles>
$\mathrm{Pd}(\mathrm{OAc})_{2}(10 \mathrm{~mol} \%)$ 47 (10 mol\%) $\mathrm{PhCOCO}_{2} \mathrm{H}(20 \sim 25 \mathrm{~mol} \%)$ $\mathrm{Ag}_{2} \mathrm{CO}_{3}$ (1.5 equiv.) $\mathrm{Li}_{2} \mathrm{CO}_{3}$ (2.0 equiv.) $\mathrm{THF}, 50^{\circ} \mathrm{C}, 72 \mathrm{~h}$

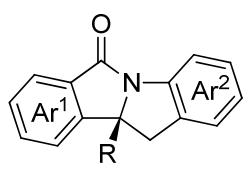

48, up to $98 \%$ yield and $-99 \%$ ee

Chen and He's work

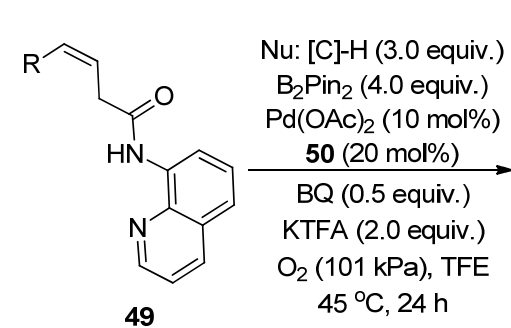<smiles>[R]C(N)C(CC(=O)Nc1cccc2cccnc12)Cc1ccccc1</smiles>

51, up to $96 \%$ yield and $97 \%$ ee

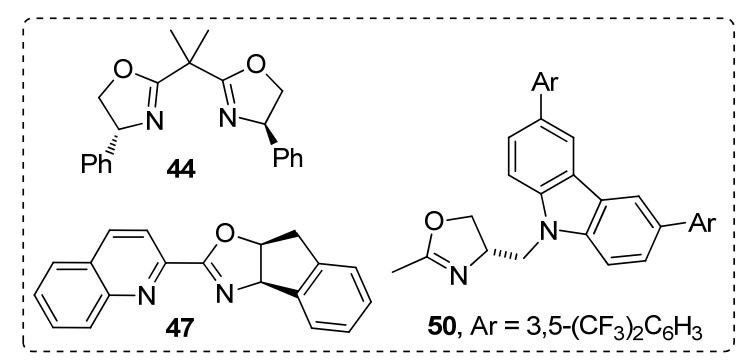

图式 10 烯烃的不对称双官能团化反应

Scheme 10 Asymmetric difunctionalization of olefins

上述烯烃的双官能团化反应中, 烯烃都有一个共同 的特点, 均借助分子内辅助基团对双键进行活化, 然后 实现其分子内双键双官能团化反应，对于分子间的反 应，具有辅助基团的底物是反应发生的关键. 在我们课 题组 ${ }^{[21]}$ 报道的烯烃 $\mathbf{5 3}$ 与炔酰胺 $\mathbf{5 2}$ 的分子间不对称氧化 环化反应中, 胺基作为辅助基团既是构筑手性中心的关 键，又是反应发生的关键. 该反应在温和的反应条件下， 以高的收率和对映选择性得到系列产物. 反应中, 首先, 二价钯和炔的参键络合形成中间体 $\mathbf{A}$, 使得碳碳参键活 化，氯离子反向进攻活化的参键形成乙烯基钯中间体 $\mathbf{B}$ (B 空间效应影响决定产物的非对映选择性); 随后 $\mathbf{B}$ 完 成对烯烃迁移插入得到中间体 $\mathbf{C}, \mathbf{C}$ 接着水解和还原消 
除得到目标产物, 催化剂经过氧化再生, 完成催化循环 (Scheme 11).

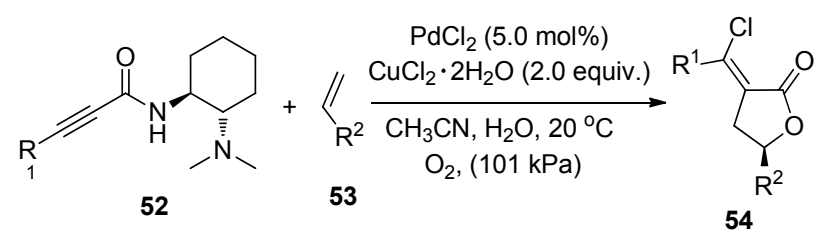
up to $82 \%$ yield up to $90 \%$ ee

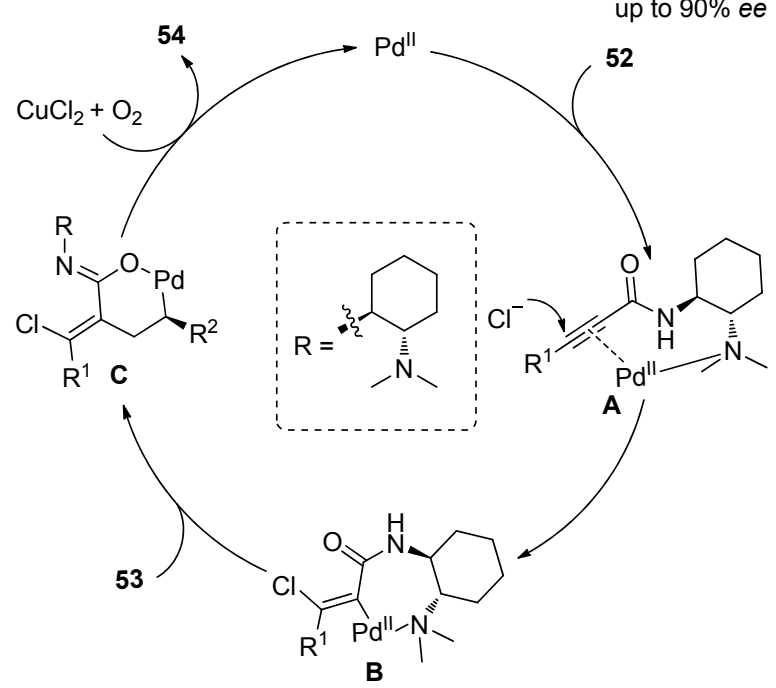

图式 $11 \mathrm{Pd}$ 催化的烯烃的不对称氧化环化反应

Scheme 11 Pd-catalyzed asymmetric oxidation cyclization of olefins

2017 年, 韩志勇课题组 ${ }^{[22 \mathrm{c}]}$ 报道了芳基嫝 63 与共轭 二烯 55 的胺化环化反应，一步合成了吲哚啉并在其位 实现了手性中心的构筑; 2018 年, 龚流柱课题组 ${ }^{[22 \mathrm{a}]}$ 报道 了二烯与脲在钯盐和手性吡啶噁唑啉配体的络合物的 催化作用下, 实现了共轭二烯 $\mathbf{5 5}$ 的 3 号位双键的不对称 胺化反应. 反应中与配体络合物和端烯双键络合脲中, 氮原子进攻活化双键完成催化剂的迁移插入形成烯丙 基钯，最后烯丙基钯还原消除得到目标产物; 随后，龚 流柱课题组 ${ }^{[22 \mathrm{~b}]}$ 在芳基脲的研究基础上, 把反应拓展到 烷氧基芳基酰胺. 首次实现了共轭二烯 60 与其的不对 称胺化反应. 该反应中钯和配体络合物催化剂与形成中 间体芳基钯物种，然后芳基钯物种对双键进行迁移插入 形成烯丙基钯，最后通过烯丙基钯的还原消除，实现目 标产物 62 的合成(Scheme 12).

2019 年, 刘国生课题组 ${ }^{[23]}$ 在该课题组发展的铜催 化的研究基础上，首次实现了芳基烯烃 66 的不对称膦 氧基化反应. 作者认为该反应首先是一价铜与叔丁基过 氧化物作用, 得到二价铜以及叔丁氧基自由基; 叔丁氧 基自由基与亲核试剂亚磷酸进行单电子转移过程(SET) 传递过程, 得到的相应膦自由基随后对烯烃进行自由基 加成生成苄基自由基; 接着，二价铜捕获苄基自由基得
Gong's work

$$
\sum_{\mathbf{5 6}}^{+} \mathrm{R}^{2} \mathrm{HN}_{\mathrm{NHR}^{3}} \frac{\begin{array}{c}
\mathrm{Pd}(\mathrm{OTs})_{2}(\mathrm{MeCN})_{2} \\
(10 \mathrm{~mol} \%)
\end{array}}{\mathbf{5 7 ( 2 4 \mathrm { mol } \% )}}
$$

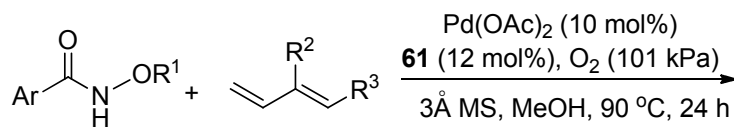

$59 \quad 60$<smiles>[R]C=C([R])[C@@H]1Cc2ccccc2C(=O)N1O[R]</smiles>

62, up to $97 \%$ yield and $94 \%$ ee

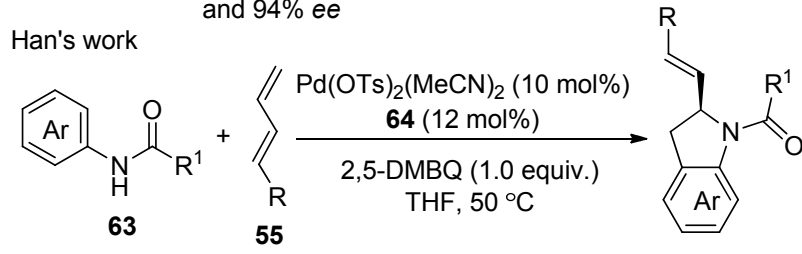

65 up to $99 \%$ yield and $90 \%$ ee

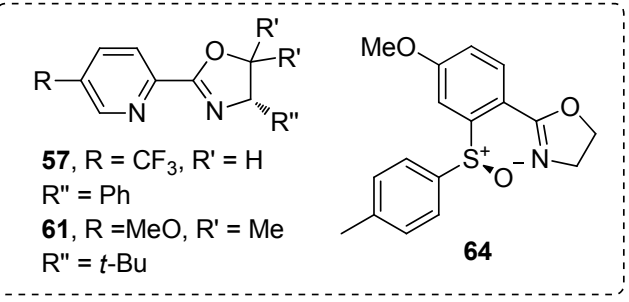

图式 12 烯烃的不对称氧化胺化反应

Scheme 12 Asymmetric oxidative amination of olefins

到三价铜物种; 最后三价铜物种还原消除得到目标产物 (S)-68. 同年, Lin 等 ${ }^{[24]}$ 发展了铜催化的电化学氧化烯烃 的不对称膦氰基化反应. 作者利用电化学合成方法，在 铜和 $N$-位酯基的双噁唑啉配体 69 作用下，以高的反应 对映选择性得到 $(R)-68$ 产物. 通过实验证明二价 $\mathrm{CuCN}$ 物种是膦自由基产生的关键(Scheme 13).

\section{3 烯烃不对称氧化 Heck 反应}

Heck 反应是烯烃反应中的一个经典反应类型，氧 化 Heck 反应为烯烃官能团化提供更多可能路径，因此 烯烃不对称氧化反应中, 不对称氧化 Heck 反应的研究 也成为研究热点.

Mikami 课题组 ${ }^{[25]}$ 报道了首例不对称氧化 Heck 反 应，以醋酸钯为催化剂，手性磺酰胺-啞唑啉 71 为配体, 在过氧苯甲酸的存在下得到中等 $e e$ 值. 反应中首先通 过钯催化苯环的碳-氢键活化，得到的芳基钯物种迁移 插入到烯烃，随后 $\beta$-氢消除得到目标产物。产物的 


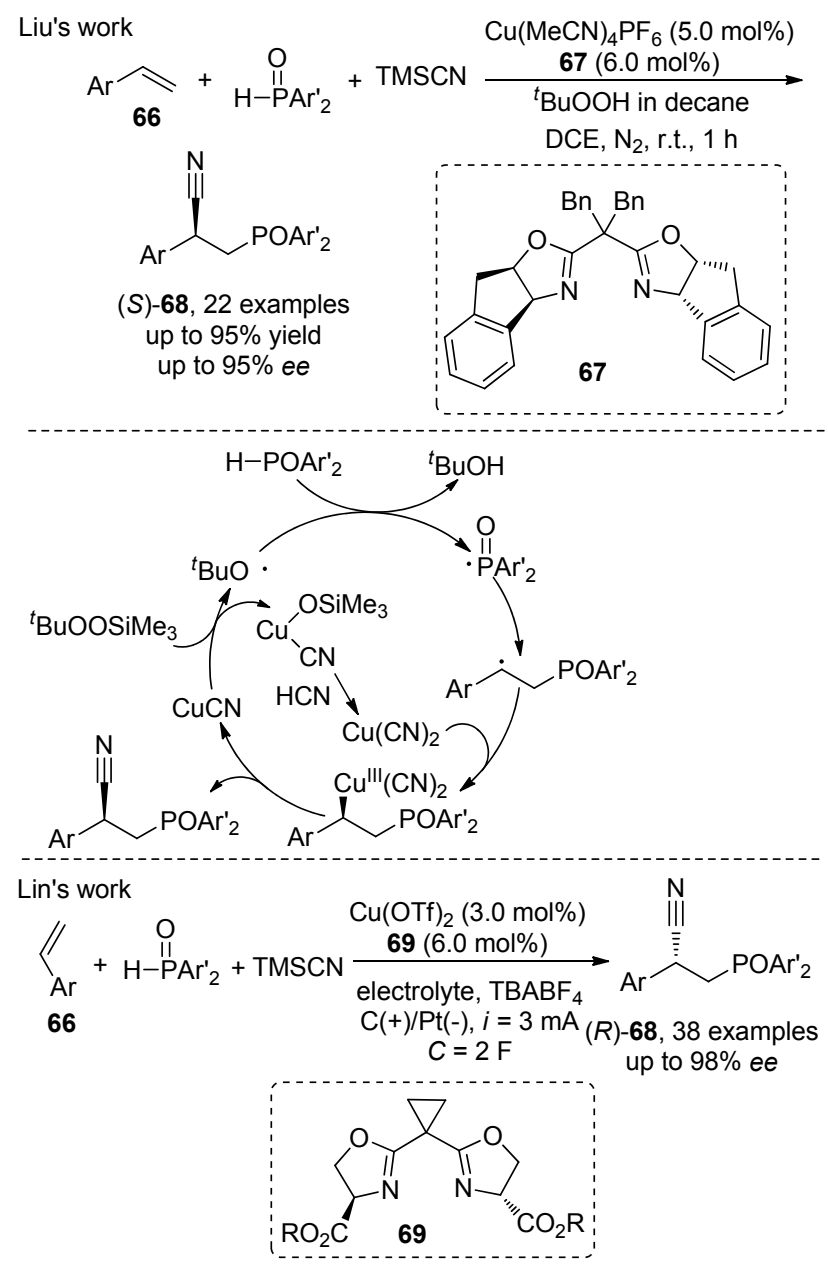

图式 $13 \mathrm{Cu}$ 催化的不对称膦氰基化反应

Scheme $13 \mathrm{Cu}$-catalyzed asymmetric reaction of phosphine cyanation

手性中心构筑是由 1,2-迁移插入决定的(Scheme 14).

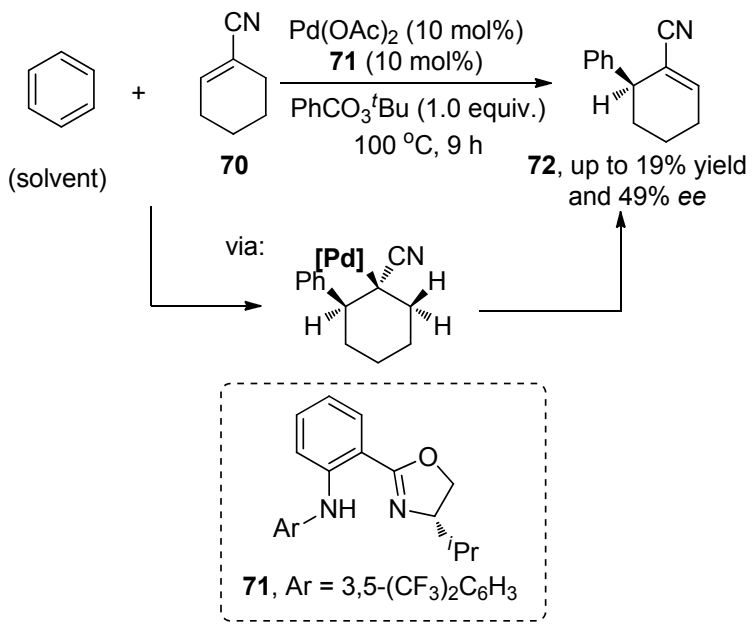

图式 $14 \mathrm{Pd}$ 催化的不对称氧化 Heck 反应

Scheme 14 Pd-catalyzed asymmetric oxidation Heck reaction

随后, Oestreich 课题组 ${ }^{[26]}$ 发展了吲哚的 2 号位的碳-
氢键活化与分子内烯烃的氧化 Heck 反应. 反应利用醋 酸钯和配体 74 的络合物为催化剂和对苯醌为氧化剂, 可以得到良好的反应收率及中等 $e e$ 值(Scheme 15). 2010 年该课题组将分子内烯烃片段引入吲哚的 3 号位，通过 相似的反应条件得到相应的手性环化产物.

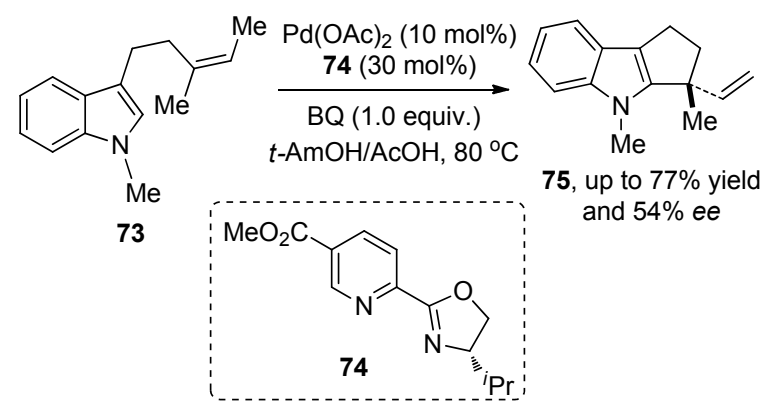

图式 15 吲哚分子内不对称氧化 Heck 反应

Figure 15 Asymmetric oxidation of Heck reaction in the indole molecule

2015 年, Sigman 等 ${ }^{[27]}$ 应用该课题组发展起来的不 对称 Heck 反应体系, 成功地实现了吲哚 76 的 3 位碳氢 键与多取代烯烃 77 的分子间氧化 Heck 反应。通过碳氢 键的活化与迁移插入得到的烷基钯中间体，经过链迁移 得到羟基 $\alpha$-位烷基钯物种，随后中间体钯不断进行插入 与反插入，最后发生 $\beta$-氢消除得到相应的产物酮 79 (Scheme 16).

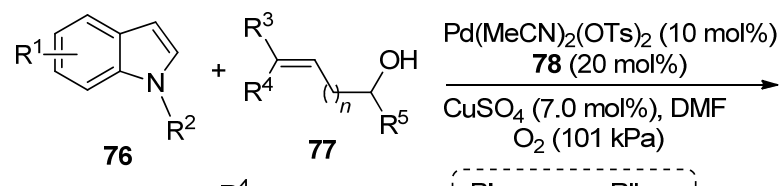<smiles>[R5]C(=O)[Al]CC([R1])([R])c1cn([R])c2cc([R1])ccc12</smiles>

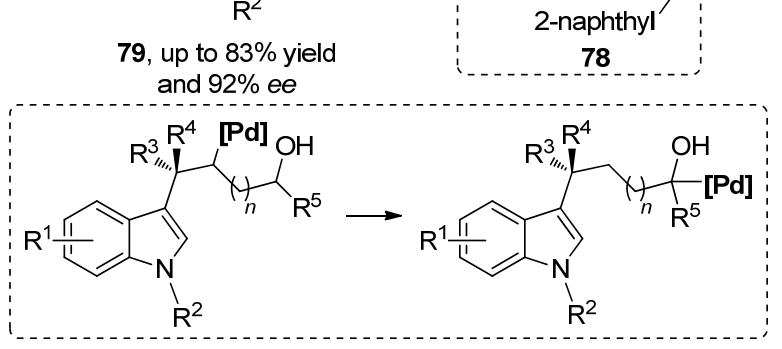

图式 16 吲哚分子间的不对称氧化反应

Scheme 16 Intermolecular asymmetric oxidative of indole

嗍酸因其特殊性质从而在不对称氧化 Heck 反应中 得到系列研究和应用. Mikami 课题组 ${ }^{[28]}$ 发展了硼酸与 $\alpha, \beta$-不饱和环烯羧酸酯 80 的 2 号碳的不对称氧化 Heck 反应. 反应中，首先是钯催化剂和嗍酸的转金属化反应, 
接着进行双键的迁移插入形成烷基钯物种，最后通过 $\beta$ 氢消除得到产物 82. 随后, Jung 课题组 ${ }^{[29]}$ 将此类型的反 应拓展到多取代链状 $\alpha, \beta$-不饱和类化合物 $\mathbf{8 3}$, 在系列的 底物实验中, 均能够得到较好的 $e e$ 值. 值得注意的是, 该反应最后没有涉及 $\beta$-氢消除的过程, 而是经过烷基钯 的还原消除得到目标产物. 2020 年, 祝介平课题组 ${ }^{[30]}$ 将 此类反应应用到 $\alpha, \beta$-不饱和环烯䊣酸脂 86 的 4 号碳的 不对称氧化 Heck 反应，反应历程与上述反应基本相似， 不同的是酰胺的羰基氧与钯催化剂发生配位, 从而实现 产物的动态动力学拆分过程(Scheme 17).

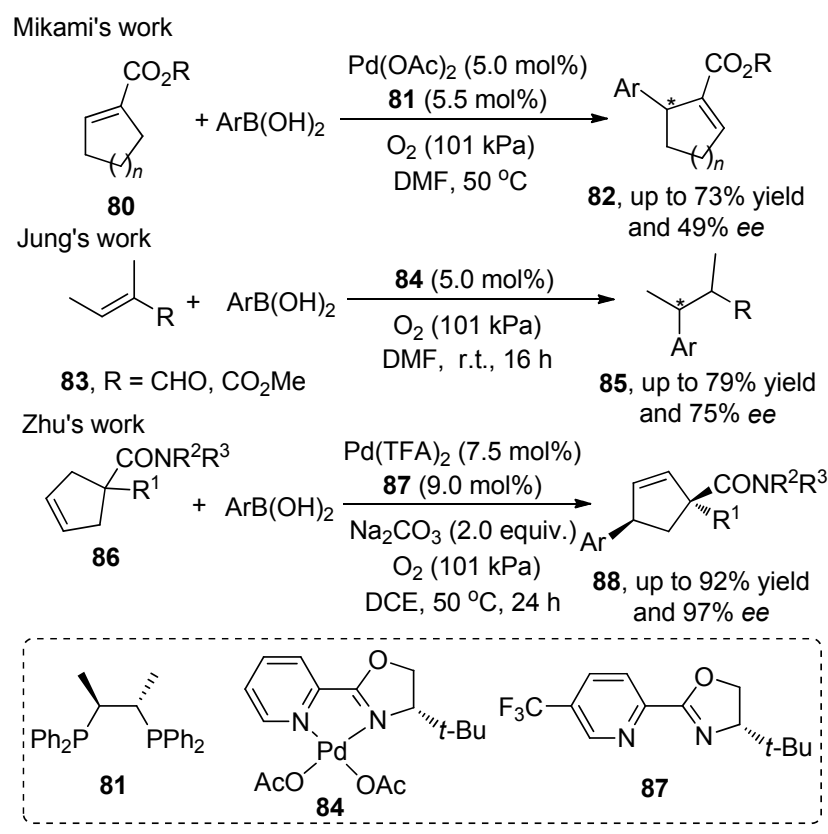

图式 $17 \mathrm{Pd}$ 催化的烯烃的不对称 Heck 反应

Scheme 17 Pd-catalyzed asymmetric Heck reaction of olefins

对于共轭洗酮类化合物, Lee 等 ${ }^{[31 \mathrm{a}]}$ 在 2015 年首次报道 了环烯二酮的不对称氧化 Heck 反应. 在钯催化剂和氧 气条件下, 以高产率和对映选择性得到产物. 随后, 他 们 ${ }^{[316]}$ 将反应底物发展到刚性结构的烯酮底物中, 与之 不同的是, 在硼酸的转金属化和对烯烃双键的迁移插入 完成后, 最后没有进行反插入过程, 而是通过还原消除 得到产物; 值得注意的是在构筑手性叔碳中心的同时实 现了刚性结构中五个碳原子的非对映选择性(Scheme 18).

在早些时候, Sigman 课题组 ${ }^{[32 a]}$ 利用多取代的烯醇 化合物 97 为底物, 在钯和手性吡啶噁唑啉配体 87 的络 合物作用下，实现了其与嗍酸的分子间不对称氧化 Heck 反应. 反应通过硼酸和钯催化剂的转金属化启动, 然后对双键迁移插入形成烷基钯，随后经过中间体钯的 反复插入和反插入，最后通过 $\beta$-氢消除完成目标产物

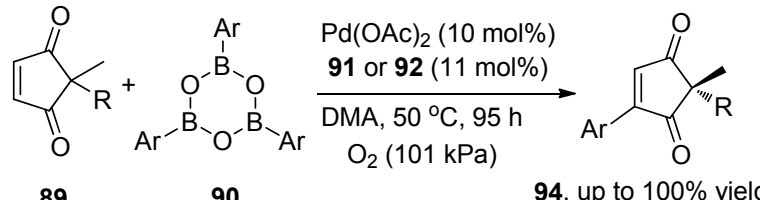

89 90 and $88 \%$ ee<smiles>[R]C1=C([R])C2([R])C3C(=O)C=CC(=O)C3C1([R])C2([R])[R]</smiles>
$\mathrm{Pd}(\mathrm{OAc})_{2}(5.0 \mathrm{~mol} \%)$ 91, 92 or $93(6.0 \mathrm{~mol} \%)$ $\mathrm{DMF}, 40^{\circ} \mathrm{C}, \mathrm{O}_{2}(101 \mathrm{kPa})$

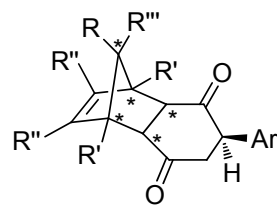

96, up to $83 \%$ yield and $96 \%$ ee

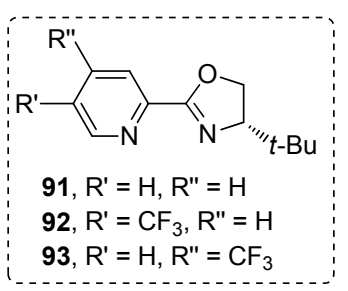

图式 18 环烯二酮的不对称 Heck 反应

Scheme 18 Asymmetric Heck reaction of cyclodienedione

98 的合成. 2016 年, 该课题组 ${ }^{[32 b]}$ 在上述研究基础上发 展了端基芳基烯醇 99 的氧化 Heck 反应, 以高度的对映 选择性得到一系列产物，反应机理同前面反应类似，通 过反复的插入、反插入和 $\beta$-氢消除得到手性酮类化合物 101 (Scheme 19).

2014<smiles>[R]C/C(C)=C/C([O])CO[13CH3]</smiles>

97

$\mathrm{R}$ -

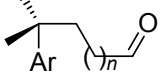

98, up to $81 \%$ yield and $98 \%$ ee

2016

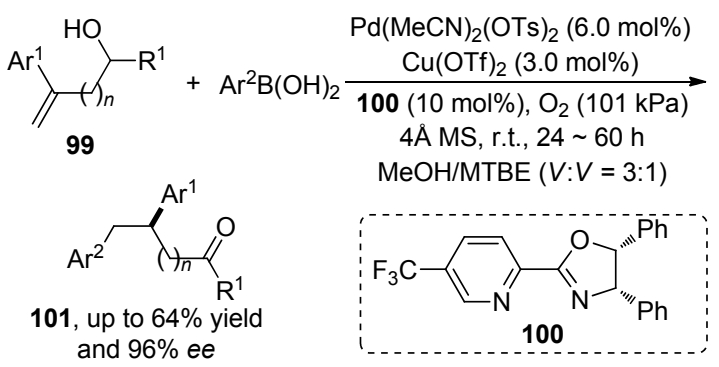

图式 19 硼酸与烯烃的不对称 Heck 反应

Scheme 19 Asymmetric Heck reaction of boric acid and olefins

$\mathrm{Yu}$ 等 ${ }^{[33]}$ 报道的二芳基乙酸 102, 在钯催化剂和氧化 剂作用下，实现了其与端烯的不对称氧化 Heck 反应. 反应首先是钯络合物促进邻位苯基 $\mathrm{C}-\mathrm{H}$ 活化, 随后催 化剂钯络合物与底物羧酸形成中间体钯物种, 然后该钯 物种对烯烃双键进行迁移插入得到烷基钯物种，最后反 插入得到目标产物 104 (Scheme 20). 


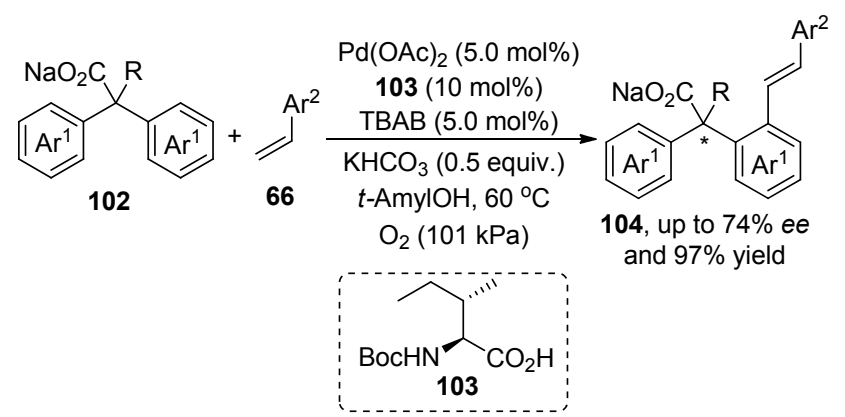

图式 20 二芳基乙酸与端烯的不对称氧化反应

Scheme 20 Asymmetric oxidation of diarylacetic acid with terminal olefins

2013 年, 吴养洁和崔秀灵课题组 ${ }^{[34 a]}$ 报道了二茂铁 103 与端烯 53 在钯催化剂和氧化剂的作用下的不对称 氧化 Heck 反应. 该方法通过底物中环戊烯中氨基官能 团来实现其邻位 $\mathrm{C}-\mathrm{H}$ 活化, 从而促进反应的发生. 在 底物实验中, 带吸电子取代基的烯烃和芳基烯烃均可以 得到较高的产率和 $e e$ 值, 含吸电子取代基的不饱和烯 酸脂的反应效果优于芳基烯烃. 随后, 他们 ${ }^{[34 b]}$ 把二茂 铁取代官能团发展到羧酸官能团底物 105 , 在醋酸钯和 氧气的作用下, 以极高的收率和对映选择性得到一系列 目标产物. 底物实验表明, 基团效应对于该方法影响较 大, 芳基烯烃反应产率明显低于不饱和烯酸脂, 原因是 苯环的空间效应不利于烯丙基钯物种对双键迁移插入 (Scheme 21).

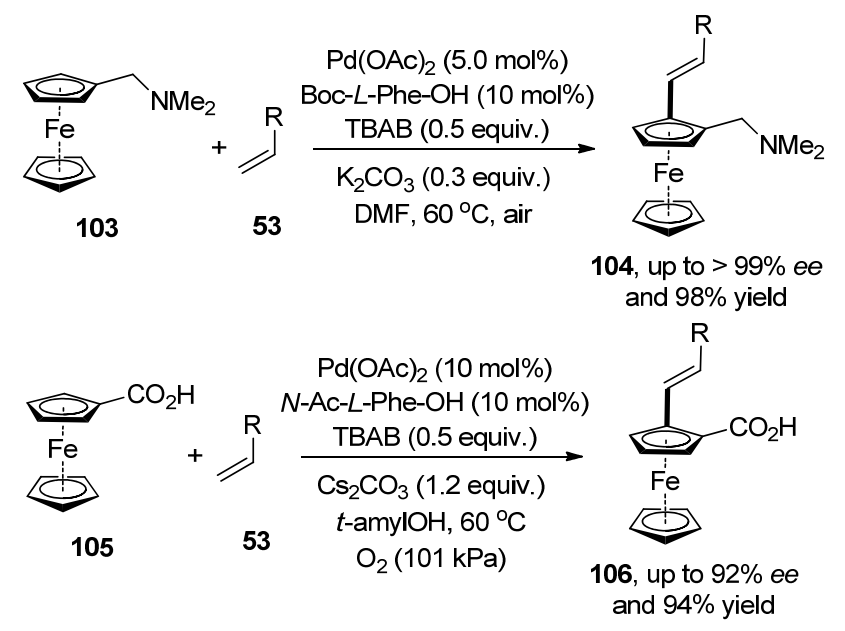

图式 21 二茂铁的不对称 Heck 反应

Scheme 21 Asymmetric Heck reaction of ferrocene

Heck 反应不仅可以实现面手性分子的构筑，也同 样可以实现轴手性分子的构筑. 如 2016 年, 游书力课题 组 ${ }^{[35]}$ 报道了 $\mathrm{Rh}$ 络合物催化的构筑轴手性分子的氧化 Heck 反应. 在催化剂和氧化剂的作用下, 多数底物以优 异的对映选择性得到产物. 反应中首先钯催化剂促进 $\mathrm{C}$ - $\mathrm{H}$ 活化, 后与底物中氮原子络合, 随后对烯烃双键进
行迁移插入得到烷基铑中间体，最后烷基铑通过反插入 得到产物(Scheme 22).

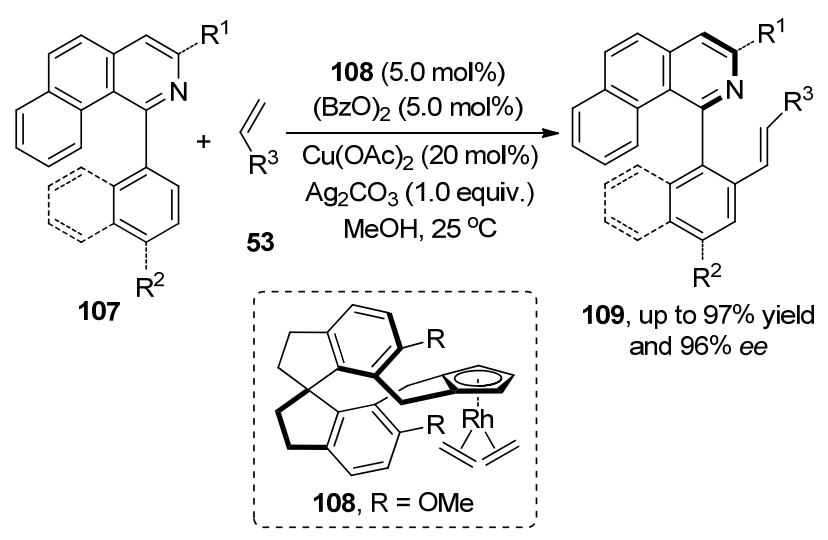

图式 $22 \mathrm{Rh}$ 催化的不对称氧化 Heck 反应

Scheme 22 Rh-catalyzed asymmetric oxidation Heck reaction

不对称氧化 Heck 反应在化合物动态拆分中可以取 得很好的拆分效果. 2016 年, Yu 课题组 ${ }^{[33 b]}$ 利用芳基乙酸 110 的 Heck 反应, 实现了其动力学拆分. 在醋酸钯、手 性氨基酸配体和氧气作用下，分子中单一构型 $(S)-\mathbf{1 1 0}$ 发生 Heck 反应，以高的对映选择拆分出另一种构型的 (R)-110 分子(Scheme 23).

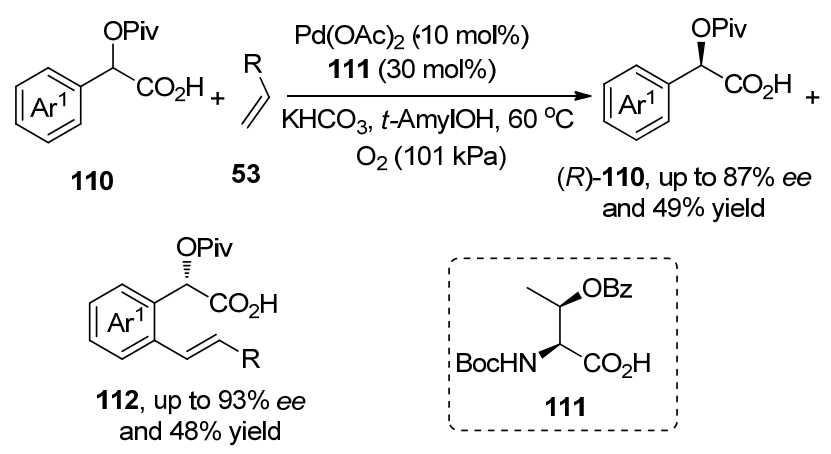

图式 23 不对称 Heck 反应动力学拆分

Scheme 23 Kinetic resolution of asymmetric Heck reaction

\section{4 烯烃不对称 Wacker 氧化反应}

近年来，金属催化的不对称 Aza-Wacker 氧化反应 取得了一系列的进展，成为构建手性含氮杂环化合物一 类重要合成策略.

自首例不对称 Aza-Wacker 氧化反应被报道以来, 经过近年来的发展，开发出了一系列高效的合成路径. 在 McDonald 等 ${ }^{[36]}$ 报道的烯烃 113 的对映选择性分子内 氧化酰胺化反应中, 利用 $\mathrm{Pd}$ 和手性吡啶噁唑啉 114 络合 物为催化剂, 能够得到中等及以上产率和较高的对映选 择性. 反应通过钯催化剂与底物的双键和氨基氮原子络 合，然后发生迁移插入过程形成烷基钯物种，最后通过 $\beta$-氢消除得到产物 115 (Scheme 24). 


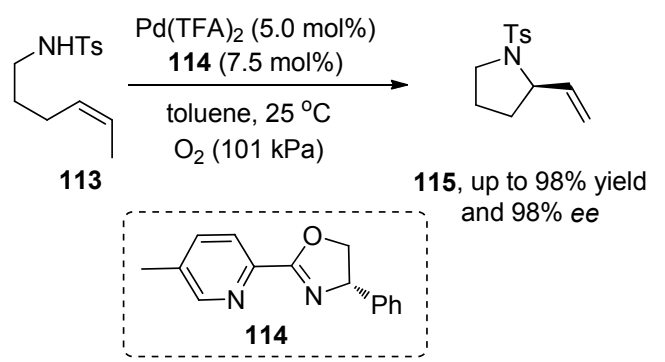

图式 24 烯胺分子内不对称氧化胺化反应

Scheme 24 Intramolecular asymmetric oxidative amination of enamine

随着研究的深入, 不对称 Aza-Wacker 氧化反应从 简单的烯胺底物拓展到复杂或者多氮杂烯胺的研究. 杨 丹课题组 ${ }^{[37]}$ 以双烯 115 分子为底物, 在 Pd 和手性吡啶 噁唑啉 116 络合物催化剂和氧化剂的作用下, 实现了手 性双环产物的构建. 作者提出的催化模型, 很好地解释 了控制其对映选择性的方式. 从机理来看, 反应是通过 钯催化剂与底物中 $\pi$ 键和氮原子络合, 然后对双键进行 迁移插入形成烷基钯物种, 最后通过二次的迁移插入和 还原消除得到目标产物 117. 随后, 祝介平课题组 ${ }^{[38]}$ 发 展了 2,5-环已二烯胺 $\mathbf{1 1 8}$ 的不对称 Wacker 氧化反应, 反 应在钯络合物催化剂和氧气条件下, 得到中等的产率以 及高的 $e e$ 值, 而且在构建了新的手性中心同时得到高 的非对映选择性(Scheme 25).

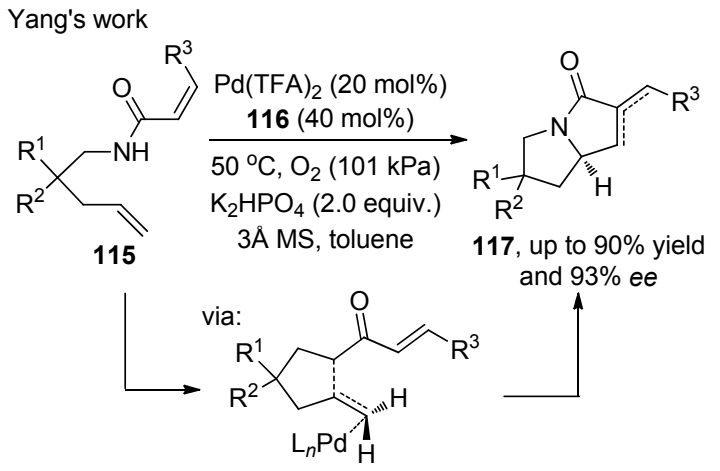

Zhu's work
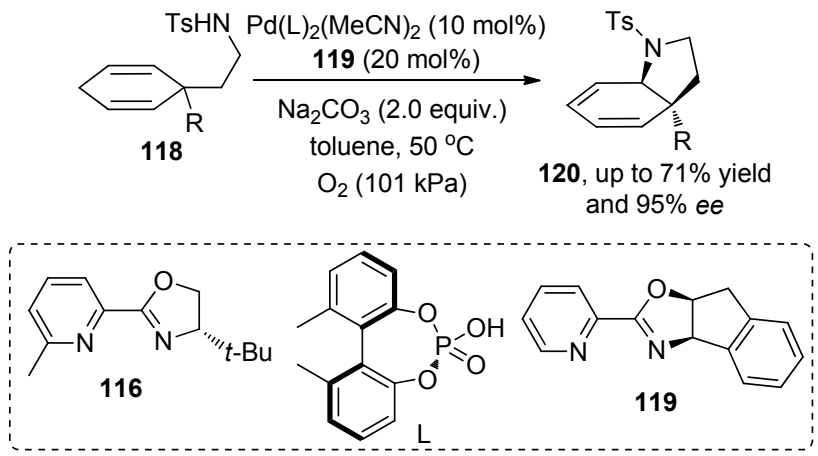

图式 25 酰胺分子内不对称 Wacker 反应

Scheme 25 Intramolecular asymmetric Wacker reaction of amide
2018 年，张万斌课题组 ${ }^{[39]}$ 报道了腙类化合物 $\mathbf{1 2 1}$ 的 不对称 Wacker 氧化反应，该反应在钯和手性吡啶噁唑 啉 122 络合物催化剂作用下, 通过对分子内双键迁移插 入得到的烷基钯，最后发生 $\beta$-氢消除得到具有光化学活 性的吡唑啉 123. 该反应成功地将此类反应应用于多氮 杂环的产物合成(Scheme 26).
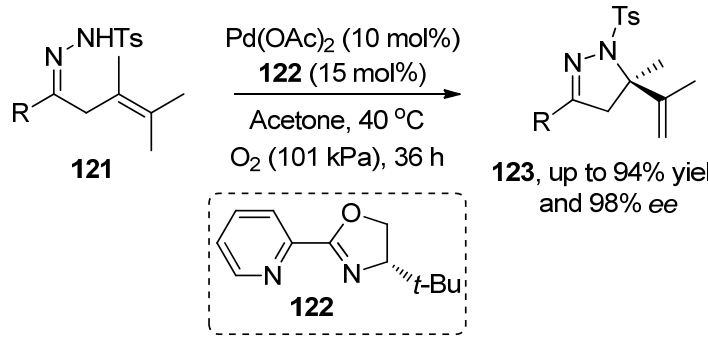

123, up to $94 \%$ yield and $98 \%$ ee

图式 26 烯肼类化合物的不对称 Wacker 反应 Scheme 26 Asymmetric Wacker reaction of enhydrazine compounds

2018 年, Sasai 等 ${ }^{[40]}$ 报道了钯与手性氮氧配体，在氧 化剂的作用下实现不对称 Wacker 氧化反应. 该反应机 理同样是钯络合物催化剂与底物络合后完成迁移插入 产生烷基钯物种，最后通过 $\beta$-H 消除得到产物. 2019 年, Sigman 等 ${ }^{[41]}$ 借助其发展的不对称氧化 Heck 催化反应体 系, 利用吲哚 $\mathrm{N}-\mathrm{H}$ 键的活性, 发展了吲哚 1 号位的不 对称 Wacker 反应. 该反应利用钯和手性吡啶噁唑啉络 合物为催化剂，在氧化剂的作用下，系列产物具有极高 的对映选择性. 底物实验中，吲哚 3 位为取代手性氨基 酸类底物会降低反应效果，而 3 号位换成同碳数胺类取 代基则有利于产物对映选择性的提高(Scheme 27).

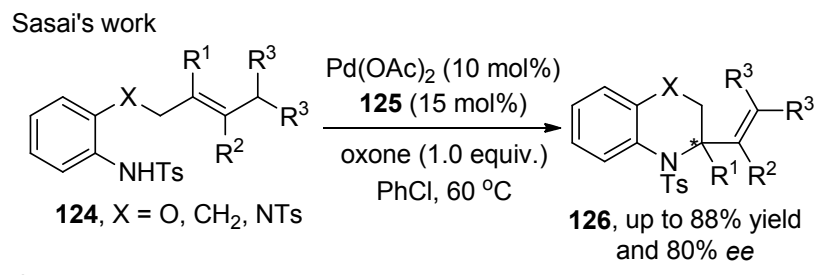

Sigman's work
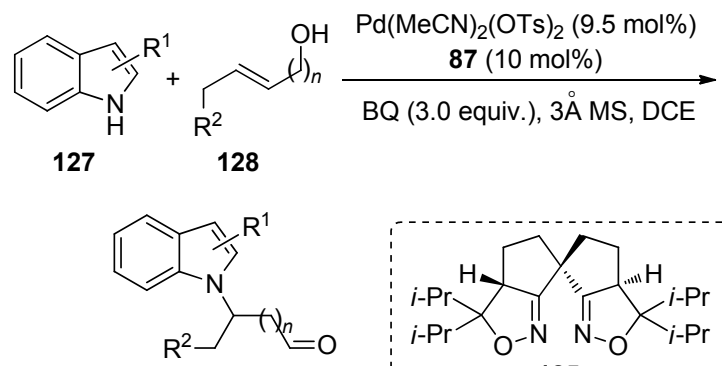

129 , up to $85 \%$ yield

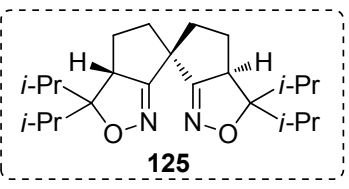
and $>98 \%$ ee

图式 $27 \mathrm{Pd}$ 催化的 $\mathrm{N}-\mathrm{H}$ 活化不对称氧化反应 Scheme 27 Pd-catalyzed asymmetric oxidation of $\mathrm{N}-\mathrm{H}$ activation 


\section{$2 \mathrm{C}$ - $\mathrm{H}$ 键的不对称氧化反应}

碳一氢键的直接不对称官能团化为手性官能团的引 入提供了最直接与有效的途径. 近年来碳-氢官能团化 领域得到了极大的发展，但是相应的 $\mathrm{C}\left(\mathrm{sp}^{3}\right)-\mathrm{H}$ 的不对 称官能团化反应仍极具挑战 ${ }^{[42]}$. 然而, 天然生物催化 剂, 如细胞色素 P450 和非血红素铁酶在 $\mathrm{C}\left(\mathrm{sp}^{3}\right)-\mathrm{H}$ 键的 高区域与对映选择性官能团化中已经显示良好的活 性 ${ }^{[43]}$ (Scheme 28).

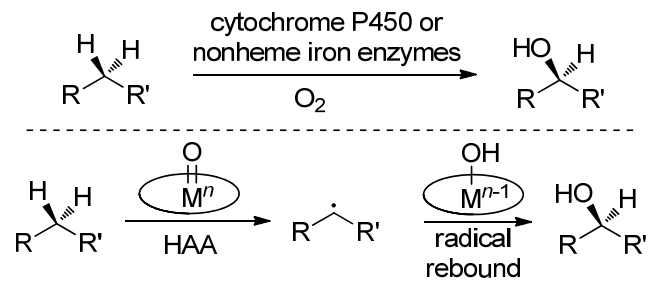

图式 28 金属酶催化不对称氧化反应

Scheme 28 Metalloenzyme catalyzesd asymmetric oxidation

在这些过程中, 常见的机理是在氧化剂的作用下形 成的金属一氧物种对烷基碳氢键发生氢原子篗取, 得到 相应的烷基自由基与价态降低一价的羟基金属中间体， 最后经过自由基的重新组合得到相应的目标产物. 在酶 催化的激励下, 化学家们设计了一系列仿生催化剂, 如 卟啉和四配位胺基吡啶类金属络合物( $\mathrm{Mn} 、 \mathrm{Fe}$ 等 $)^{[44]}$. 这 里将不进行展开讨论.

\section{$2.1 \mathrm{C}\left(\mathrm{sp}^{2}\right)-\mathrm{H}$ 键的不对称氧化反应}

在 $\mathrm{C}\left(\mathrm{sp}^{2}\right)-\mathrm{H}$ 键的反应中, 辅助基团实现分子内 $\mathrm{C}-\mathrm{H}$ 键活化是重要合成策略, 底物分子内 $\mathrm{C}-\mathrm{H}$ 键活 化后, 金属催化剂与底物中辅助官能团作用得到金属中 间体，然后通过转金属化和还原消除完成产物的生 成 ${ }^{[45]}$. 利用此合成策略已经实现卤代烃、不饱和烃以及 碀酸类化合物的不对称碳碳氧化偶联反应.

在碳氢键活化领域中, $\mathrm{Yu}$ 课题组有着丰富研究经 验. 如在 $\mathrm{Yu}^{[45]}$ 报道的分子内芳基与硼酸的不对称氧化 偶联反应中, 利用分子内吡啶为辅助基团, 在醋酸钯催 化剂和氧化剂的作用下, 反应可以得到优异的收率和 $e e$ 值. 该反应是通过辅助基团与催化剂络合实现其芳基邻 位 $\mathrm{C}-\mathrm{H}$ 键活化形成中间体钯络合物(该中间体决定着 反应的对映选择性), 然后与喼酸发生转金属化反应, 最后还原消除得到目标产物, 系列底物都具有很好的反 应结果(Scheme 29). 利用此合成策略, 该课题组 ${ }^{[46]}$ 在钯 催化剂和氧化剂作用下, 利用茮胺类化合物与嗍酸分子 间的反应实现了茮胺类化合物的动力学拆分.

2013 年, $\mathrm{Yu}$ 和 Wang 等 ${ }^{[47]}$ 首次利用二价钯到四价钯 的催化体系, 实现了苯乙酸 133 分子内的不对称氧化反 应. 反应涉及钯催化剂与羧酸根络合以及对芳基上 $\mathrm{C}-$

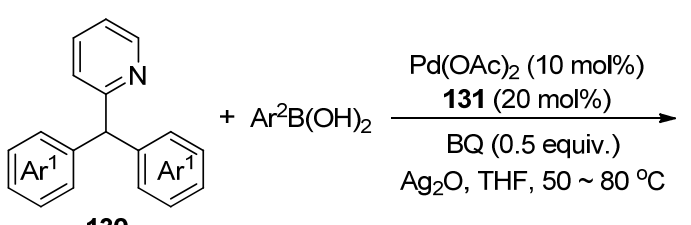

130

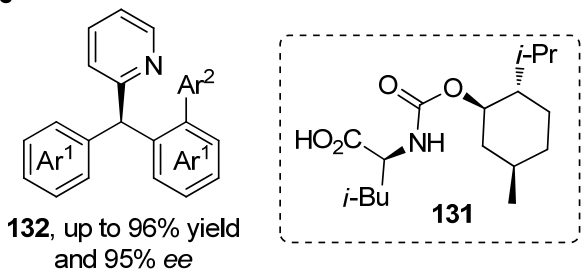

图式 292 2-苯甲基吡啶的不对称氧化反应

Scheme 29 Asymmetric oxidation of 2-benzylpyridine

$\mathrm{H}$ 活化, 随后形成分子内 $\mathrm{C}-\mathrm{O}$ 键, 得到手性苯并呋喃 酮 134, 该反应通过分子内羧酸环化实现 $\mathrm{C}-\mathrm{O}$ 的构建. 随后，韩福社课题组 ${ }^{[48]}$ 利用芳基亚磷酰胺化合物 135, 在催化剂与氧化剂的条件下，实现了芳基亚磷酰胺类化 合物与嗍酸的不对称氧化反应，与上述不同是该方法是 一个二价钯到零价钯的催化过程. 底物实验中, $\mathrm{Ar}^{2}$ 中取 代基团位置影响反应进行，间位基团能够促进反应的发 生，但底物取代基效应对产物的 $e e$ 值影响不大，该方法 中由于酰胺基团的特殊性，在一定程度限制此类方法的 应用. 两者反应均是利用辅助基团，通过有机反应实现 苄为手性中心的动力学拆分过程(Scheme 30).

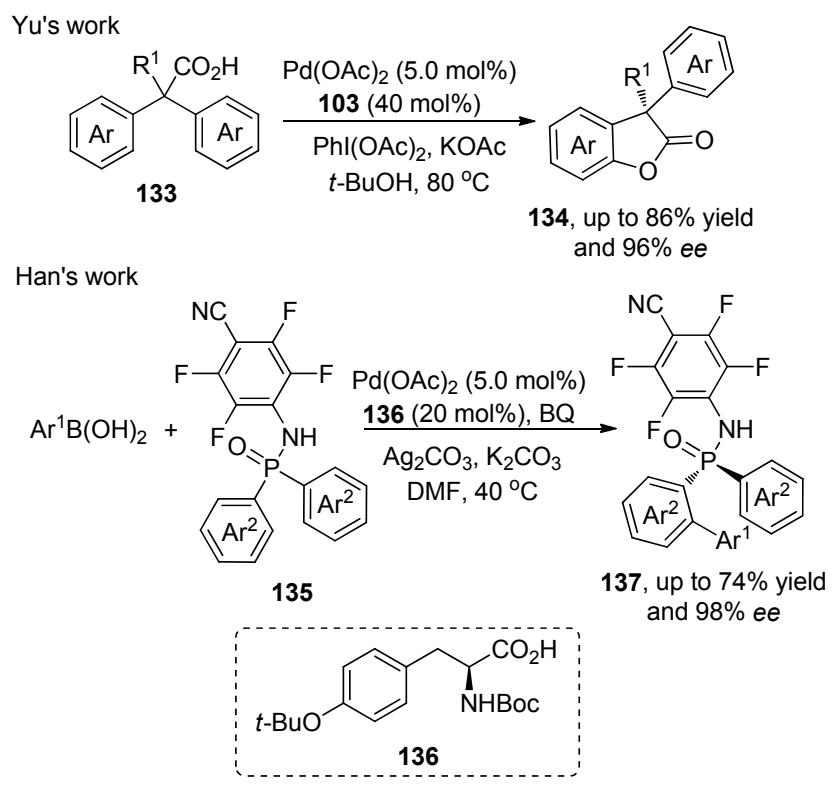

图式 30 芳基 $\mathrm{C}\left(\mathrm{sp}^{2}\right)-\mathrm{H}$ 键的不对称氧化反应

Scheme 30 Asymmetric oxidation of aryl $\mathrm{C}\left(\mathrm{sp}^{2}\right)-\mathrm{H}$ bond

2017 年, 石枫课题组 ${ }^{[49]}$ 首次报道了在 2-吲哚基甲 醇的 3 位碳构建轴手性联芳基骨架的方法，该方法是利 用有机催化剂实现的. 2020 年, 祝介平课题组 ${ }^{[50]}$ 首次在 
金属钯催化作用下，实现了吲哚 2 位碳轴手性联芳基骨 架的构建. 该方法是在 $\mathrm{Pd}(\mathrm{OAc})_{2}$ 和配体 139 与氧气作用 下, $N$-芳基(烷基)磺酰基-2-炔基苯胺 138 与芳基嗍酸反 应, 得到的 2,3-二取代吲哚 140 具有高产率和对映选择 性. 反应中钯配合物催化剂与芳基硼酸发生转金属化反 应得到芳基钯络合物, 然后与底物中参键络合经过迁移 插入得到烯基钯中间体，最后还原消除得到目标产物. 2019 年, 李兴伟课题组 ${ }^{[51]}$ 报道了轴手性分子 $2,3^{\prime}$-联吲 哚基 145 合成方法, 该方法是在 $\mathrm{Rh}$ 催化剂 143 和氧化 剂的作用下实现, 产物具有优异的 $e e$ 值. 反应首先是催 化剂完成吲哚 2 号碳氢键活化后与导向基团作用得到中 间体铑物种, 随后与炔烃络合进行迁移插入环化过程得 到烯基铑中间体, 最后烯基铑还原消除得到产物. 在控 制实验中, 作者分离出了手性的 $\mathrm{Rh}$ 环化中间体, 为机 理提供了直接证据(Scheme 31).

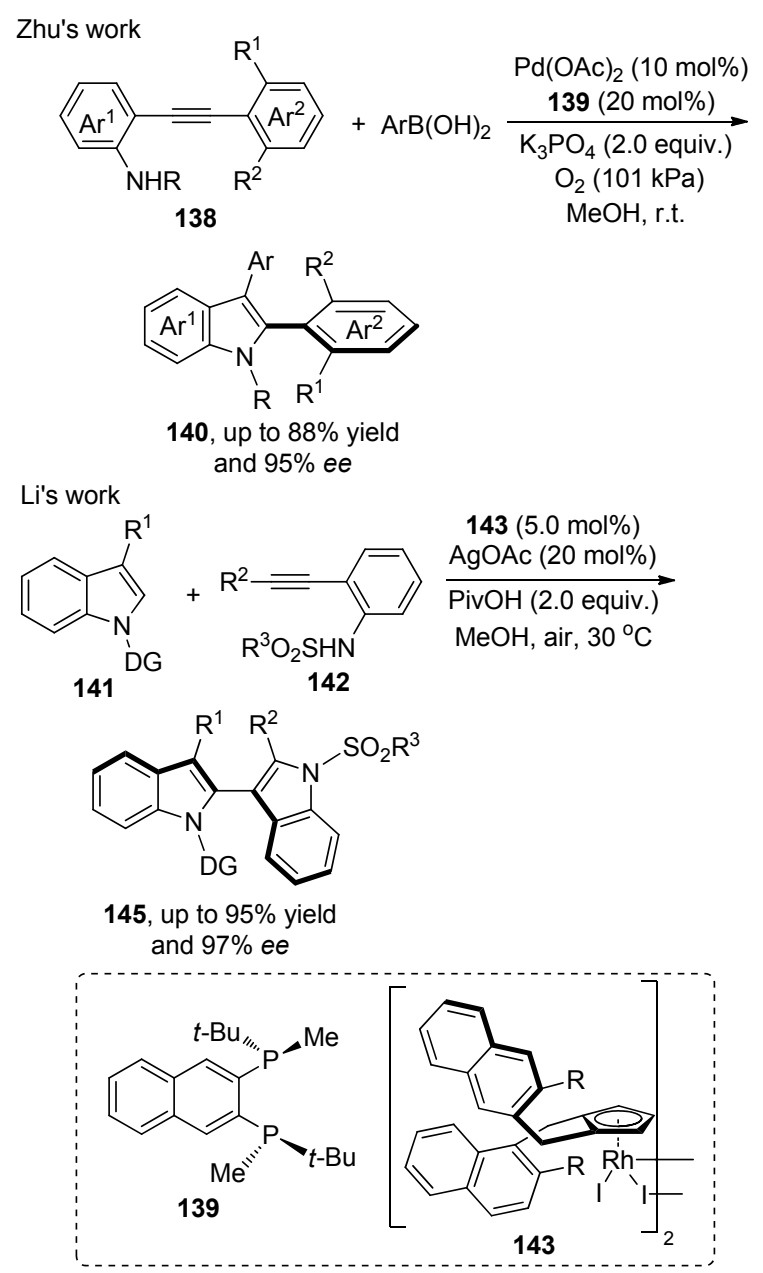

图式 31 轴手性联芳基吲哚的合成

Scheme 31 Synthesis of axial chiral biarylindole

通过 $\mathrm{C}\left(\mathrm{sp}^{2}\right)-\mathrm{H}$ 活化的策略构筑叔碳、季碳或者实 现具有手性中心的底物动力学拆分的研究工作非常成 功, 其中构筑面手性分子的研究以二茂铁为骨架较为典
型. 如游书力课题组 ${ }^{[52]}$ 在前期研究基础上发展了取代 二茂铁分别与嗍酸和内炔 149 的 $\mathrm{C}\left(\mathrm{sp}^{2}\right)-\mathrm{H}$ 氧化偶联反 应，该方法在钯催化剂和氧化剂的作用下，系列产物均 可以得到高的 $e e$ 值. 两者均借助于二茂铁辅助基团实 现其碳氢活化, 反应启动方式相似. 前者是催化剂与二 茂铁辅助基团络合促进其环戊烯 $\mathrm{C}-\mathrm{H}$ 键活化得到钯中 间体，随后与硼酸完成转金属化过程，最后通过还原消 除得到目标产物 148; 后者则是先钯催化剂与底物作用 完成 $\mathrm{C}-\mathrm{H}$ 活化过程, 再和两分子内炔进行迁移插入形 成烯基钯，最后通过内炔芳基 $\mathrm{C}-\mathrm{H}$ 键的反应进行还原 消除得到目标产物 ${ }^{[53]} \mathbf{1 5 0}$ (Scheme 32).
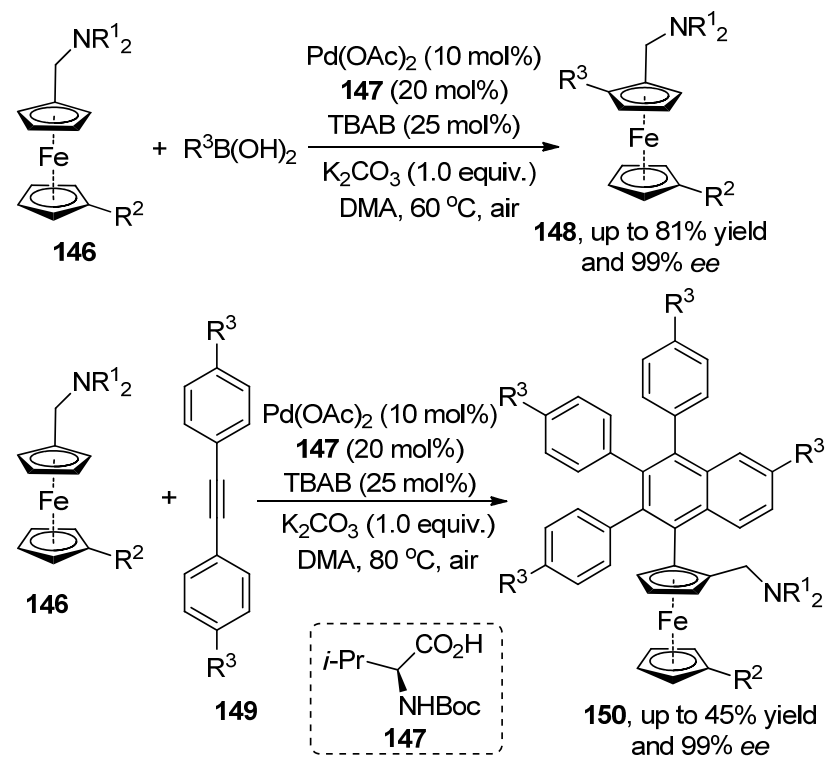

图式 $32 \mathrm{Pd}$ 催化的二茂铁不对称氧化反应

Scheme 32 Pd-catalyzed asymmetric oxidation of ferrocene

随后, 游书力课题组 ${ }^{[54]}$ 在二茂铁构建面手性产物 研究基础上，发展了二茂铁 146 和杂芳烃 151 之间的钯 催化的不对称氧化交叉偶联反应. 该反应在醋酸钯催化 剂和氧化剂的作用下进行，具有中等反应收率以及高的 对映选择性. 反应通过芳杂环和二茂铁上碳氢活化后得 到五元芳基钯中间体，最后发生还原消除构建具有面手 性的目标化合物 152. 接着他们把芳杂环拓展到芳二杂 环 154, 实现了芳二杂环与二茂铁的不对称氧化偶联反 应. 反应在醋酸钯催化剂和氧化剂的作用下实现，得到 的系列产物具有高对映选择性和收率. 底物实验中, 杂 环类底物、多取代啞唑和噻唑均能得到较高的 ee 值 (Scheme 33).

钯催化的 $\mathrm{C}\left(\mathrm{sp}^{2}\right)-\mathrm{H}$ 不对称氧化反应的不断发展, 促进了其他过渡金属催化体系在该类型的反应中应用. 如 2019 年, Cramer 等 ${ }^{[55]}$ 报道了在 Rh 络合物 158 催化剂 作用下, 链状烯酰胺 156 与联烯 157 进行[4+1]环化反 


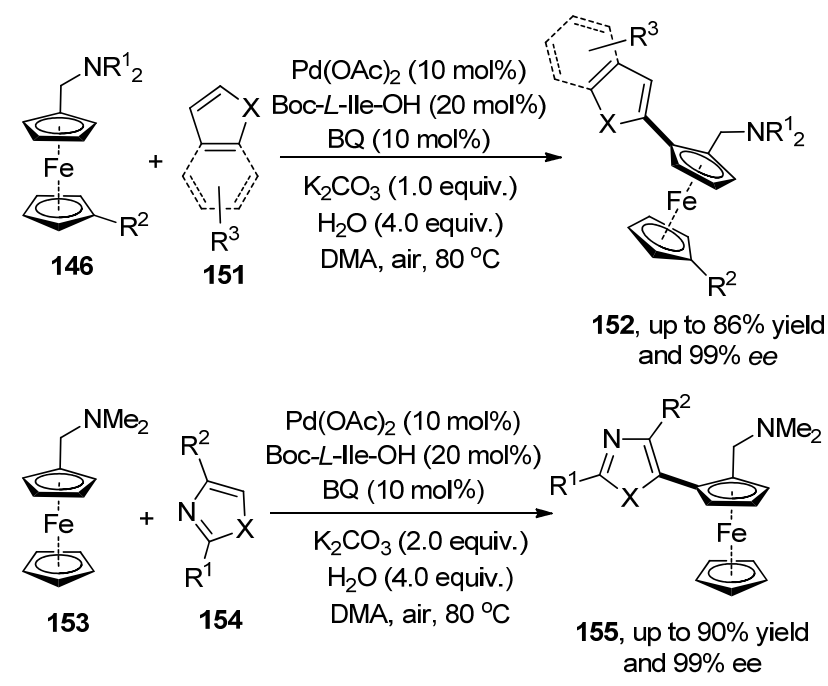

图式 33 二茂铁与芳基杂环的不对称偶联反应

Scheme 33 Asymmetric coupling reaction between ferrocene and aryl heterocycle

应. 该方法是通过 $\mathrm{Rh}$ 催化剂进行链状烯烃的 $\mathrm{C}\left(\mathrm{sp}^{2}\right)-\mathrm{H}$ 键活化, 然后对联烯双键进行迁移插入形成一个环状 $\mathrm{Rh}$ 中间体，最后该中间体发生异构化和还原消除得到 产物 159. 该反应条件温和, 具有广泛的基团耐受性和 高的对映选择性(Scheme 34).

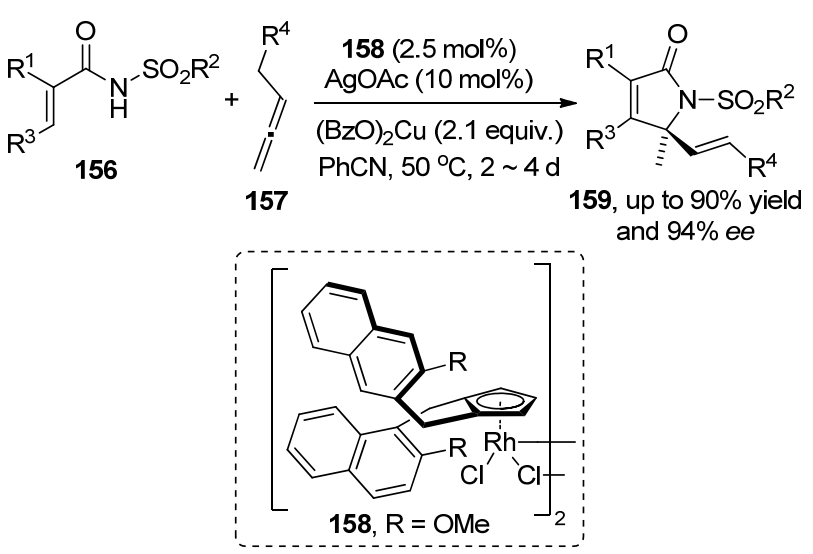

图式 $34 \mathrm{Rh}$ 催化的烯酰胺与联烯的不对称氧化反应

Scheme 34 Rh-catalyzed asymmetric oxidation of enamide and allene

\section{$2.2 \mathrm{C}\left(\mathrm{sp}^{3}\right)-\mathrm{H}$ 键的不对称氧化反应}

$\mathrm{C}\left(\mathrm{sp}^{3}\right)-\mathrm{H}$ 的活性高于 $\mathrm{C}\left(\mathrm{sp}^{2}\right)-\mathrm{H}$ 的活性, 其不对称 氧化反应的研究较为深入, 发展出了系列较为成熟的合 成策略, 其底物适用性也较为广泛, 而且将传统的热反 应发展到光反应, 使得合成朝着绿色、精准的路线发展.

2011 年, $\mathrm{Yu}$ 等 ${ }^{[56]}$ 报道了酰胺烷基的不对称氧化反 应，该反应在醋酸钯络合物催化剂和氧化剂作用下，可 以得到中等及以上的 $e e$ 值. 随后, 他们 ${ }^{[57]}$ 将反应发展到 环己烷的 2 号碳以及链状烷烃的 $\mathrm{C}-\mathrm{H}$ 键活化, 两者都 是利用硼酸类化合物为偶联分子, 均可以得到较好的反
应结果，反应的不足是受氨基取代基的限制，无法进一 步拓展其他酰胺类底物的应用(Scheme 35).
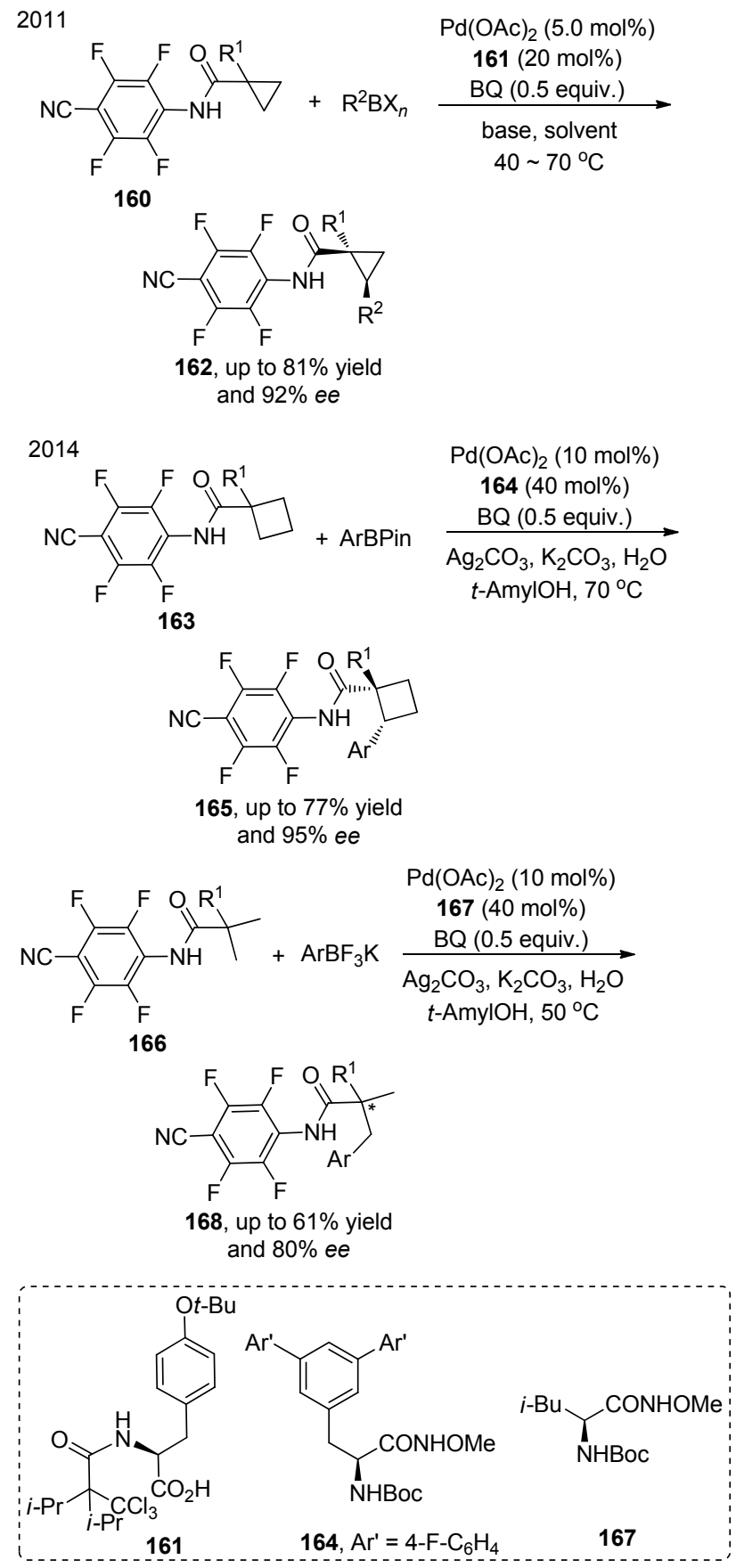

图式 $35 \mathrm{Pd}$ 催化的酰胺不对称氧化反应

Scheme 35 Pd-catalyzed asymmetric oxidation of amide

2019 年, $\mathrm{Yu}$ 等 ${ }^{[58]}$ 发展了羧酸底物的 $\mathrm{C}-\mathrm{H}$ 键不对称 反应，简化了之前反应底物的导向官能团，突破了底物 在此类反应中局限. 该反应在钯络合物催化剂和氧化剂 的作用下，可以实现三元环取代羧酸和四元环取代羧酸 环上的 $\mathrm{C}-\mathrm{H}$ 活化，整个反应过程中不改变原有底物的 对映选择性，且具有较好的 ee 值(Scheme 36). 


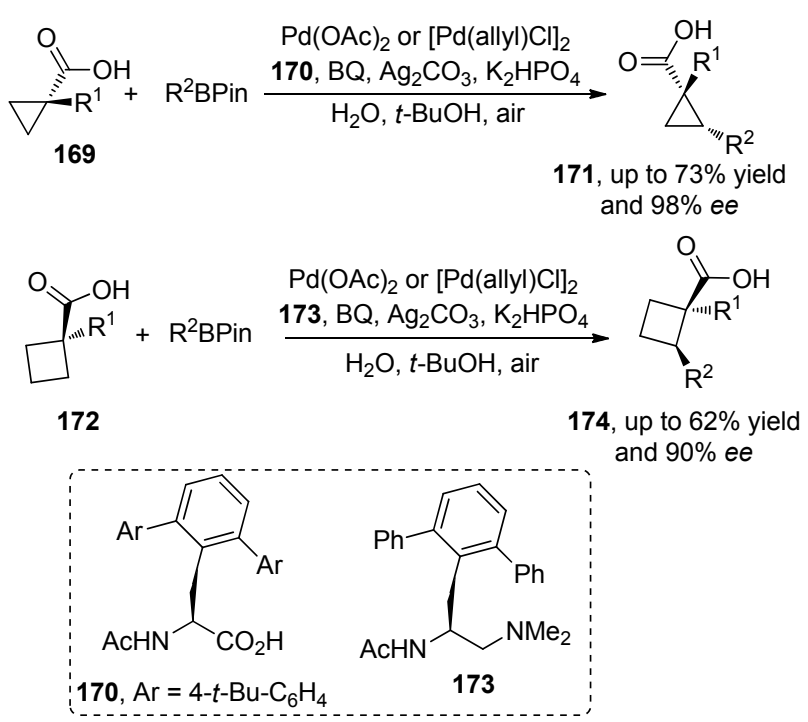

图式 36 环乙酸的不对称氧化反应

Scheme 36 Asymmetric oxidation of cycloacetic acid

活泼氢的反应在 $\mathrm{C}\left(\mathrm{sp}^{3}\right)-\mathrm{H}$ 的研究比较成熟, 如利 用 $\beta$-酮酸酯中两个羰基之间的 $\mathrm{C}-\mathrm{H}$ 键的活性构建新的 碳碳和碳杂键, 进一步转化为更有价值的分子骨架. 在 $\beta$-酮酸酯的不对称羟化反应研究中, 冯小明课题组 ${ }^{[59]}$ 和 孟庆伟课题组 ${ }^{[60]}$ 报道的合成策略, 有效地实现了 $\beta$-酮酸 酯 175 和 178 的不对称 $\alpha$-羟基化. 冯小明的报道中以 $\mathrm{Mg}$ 和 $N, N^{\prime}$-二氧化物的络合物 176 为催化剂, 过氧化氢 叔丁基(TBHP)为氧化剂; 孟庆伟的报道中以 $\mathrm{Zr}$ (Salan) 络合物 179 为催化剂, 过氧化氢异丙苯(CHP)为氧化剂. 两种方法均以较高收率和优异的对映选择性得到系列 的目标产物(Scheme 37).

随后, 人们利用光化学反应绿色环保、条件温和及 操作简单的特点, 将 $\beta$-酮酸酯的不对称 $\alpha$-差基化发展到 光化学反应中. 如肖文精课题组 ${ }^{[61]}$ 报道了可见光诱导 下, 在 182 与 $\mathrm{Ni}(\mathrm{acac})_{2}$ 形成的络合物作用下 $\beta$-酮酸酯 181 的不对称 $\alpha$-羟基化反应; 孟庆伟 ${ }^{[62]}$ 报道了可见光诱 导 $\mathrm{Cu}$ (Salan)催化 $\beta$-酮酸酯 184 的不对称 $\alpha$-差基化反应. 两种方法均使用可见光驱动反应, 氧气或空气作为氧化 剂, 获得的产物具有较高收率和对映选择性(Scheme 38). 不同的是, 前者是将配体修饰在光敏剂中, 在启动 反应的同时，配体和中心金属的作用控制了产物的对映 选择性; 后者则是通过外加手性催化剂控制产物的手 性.

在有机光反应中，依赖底物的手性诱导因素实现偶 联反应的对映选择性, 是一种常见的合成策略 ${ }^{[63]}$. 直接 构建手性中心较为有效的方法是通过底物与共催化剂 形成中间体，该中间体进一步控制偶联反应产物的对映 选择性 ${ }^{[64]}$. 2012 年, Rovis 等 ${ }^{[64]}$ 报道了手性有机催化剂 $\mathrm{N}$-杂环卡宾 189 和光催化剂组成的共催化体系, 实现了
Feng's Work

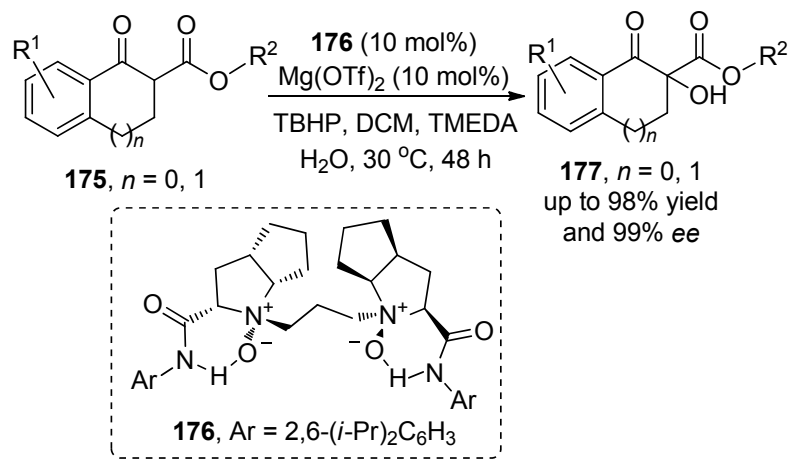

Meng's Work

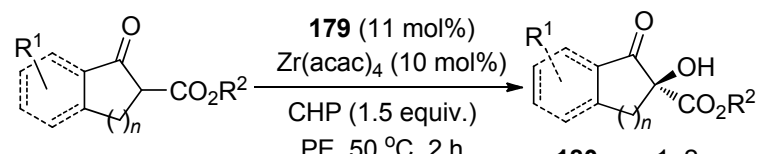

178, $n=1,2$

$\mathrm{PE}, 50^{\circ} \mathrm{C}, 2 \mathrm{~h}$

$180, n=1,2$

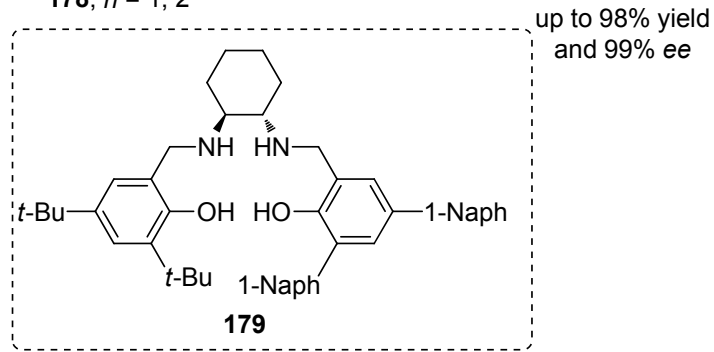

图式 37 手性 $\alpha$-差欮基二羰基化合物的合成

Scheme 37 Synthesis of chiral $\alpha$-hydroxydicarbonyl compounds

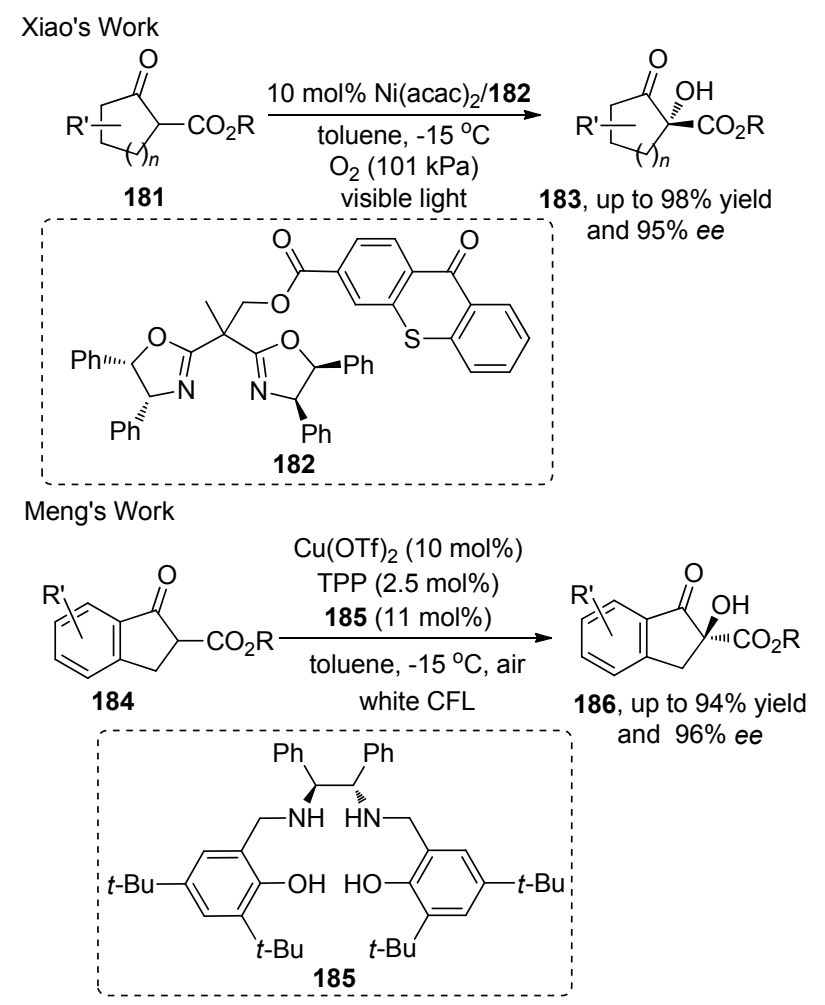

图式 $38 \beta$-酮酸酯的不对称差弪化反应

Scheme 38 Asymmetric hydroxylation of $\beta$-ketoester 
叔胺 187 与醛 188 的不对称 $\alpha$-酰化反应. 醛 188 与有机 催化剂 189 形成的中间体是决定产物对映选择性的关 键. 从机理可以看出, 反应涉及两个循环过程: 光循环 启动和有机催化剂循环生产过程. 在光催化过程中, 光 催化剂金属钌吸收光后激发成为激发态, 激发态的光敏 剂与电子受体进行电子转移, 其氧化数升高变为三价 钉, 底物胺 187 与三价钉作用, 失去一个氢自由基后胺 异构化形成亚胺正离子 $\mathbf{A}$, 而三价钓在此反应过程中, 被还原成二价钉，完成体系内光催化剂金属钉的循环; 在光催化发生的同时, 有机催化剂 189 与另一底物醛 188 形成中间体 $\mathbf{B}$, 而 $\mathbf{A}$ 与该过程中生成的中间体 $\mathbf{B}$ 进 行胺化反应生成 $\mathrm{C}$ 或者直接与 189 作用; $\mathrm{C}$ 解离出 190 生成 189 完成有机催化剂的循环再生(Scheme 39).

\section{3 烯丙基 $\mathrm{C}$ - $\mathrm{H}$ 键的不对称氧化反应}

烯丙基的碳氢官能团化反应为功能烯烃分子的构 建提供了快捷方法. 过渡金属与手性配体的不对称催化 碳一氢键氧化官能团化的反应中, Kharasch-Sosnovsky 反 应是典型的代表 ${ }^{[65]}$. 烯丙基碳氢反应发展出了系列催 化过程, 但是其手性构建发展却是缓慢的, 开发合适的 催化体系实现烯丙基位或苄位碳氢键的不对称氧化官 能团化, 仍然是一个研究热点.

刘国生课题组在该领域的研究成就显著, 主要发展 的是 $\mathrm{Cu}$ 催化的自由基反应过程, 如他们课题组 ${ }^{[66]}$ 报道
的 $\mathrm{Cu}$ 和手性双噁唑啉配体催化剂, 在不对称氧化碳-氢 键氰基化反应中得到良好的收率和 $e e$ 值. 作者认为是 一价铜催化 $N$-氟代双苯磺酰胺(NFSI)的 N-F 键的均裂, 得到相应的氮自由基与二价铜. 氮自由基与底物 191 作 用得到苄基自由基，随后被手性二价铜捕获形成中间体 铜物种，最后还原消除构建目标产物 192. 该反应中, 底物的基团可以控制氰基的进攻方向，改变产物的构 型; 在底物实验中, 大位阻和杂环类底物对反应的发生 不利，但是对其对映选择性影响不大(Scheme 40).

2019 年, 刘国生课题组 ${ }^{[67]}$ 又成功实现了在二氯乙 烷、全氟苯、 $N, N$-二甲基乙酰胺(25:3:4)的混合溶剂 中，芳基苯硼酸与苄基碳一氢键的不对称氧化偶联，得 到手性 1,1-二芳香化合物 194. 该反应成功的关键是在 手性双噁唑啉 193 配体上引入羧酸酯基，加速了芳基硼 酸的转金属作用, 避免了其他副反应的发生(Scheme $41)$.

2020 年, 刘心元课题组 ${ }^{[68]}$ 利用铜催化剂与手性磷 酸 196 的组合成功实现了分子内 $\mathrm{N}-\mathrm{H}$ 与苄基 $\mathrm{C}-\mathrm{H}$ 的 不对称氧化偶联. 该方法以高对映选择性合成了五元杂 环化合物 197 (Scheme 42).

Chai 和 Rainey ${ }^{[69]}$ 于 2012 年报道了钯/手性布朗斯特 酸 199 催化烯丙基碳氢键与分子内四元环醇的氧化偶 联. 反应涉及烯丙基碳氢活化后得到的烯丙基钯物种,

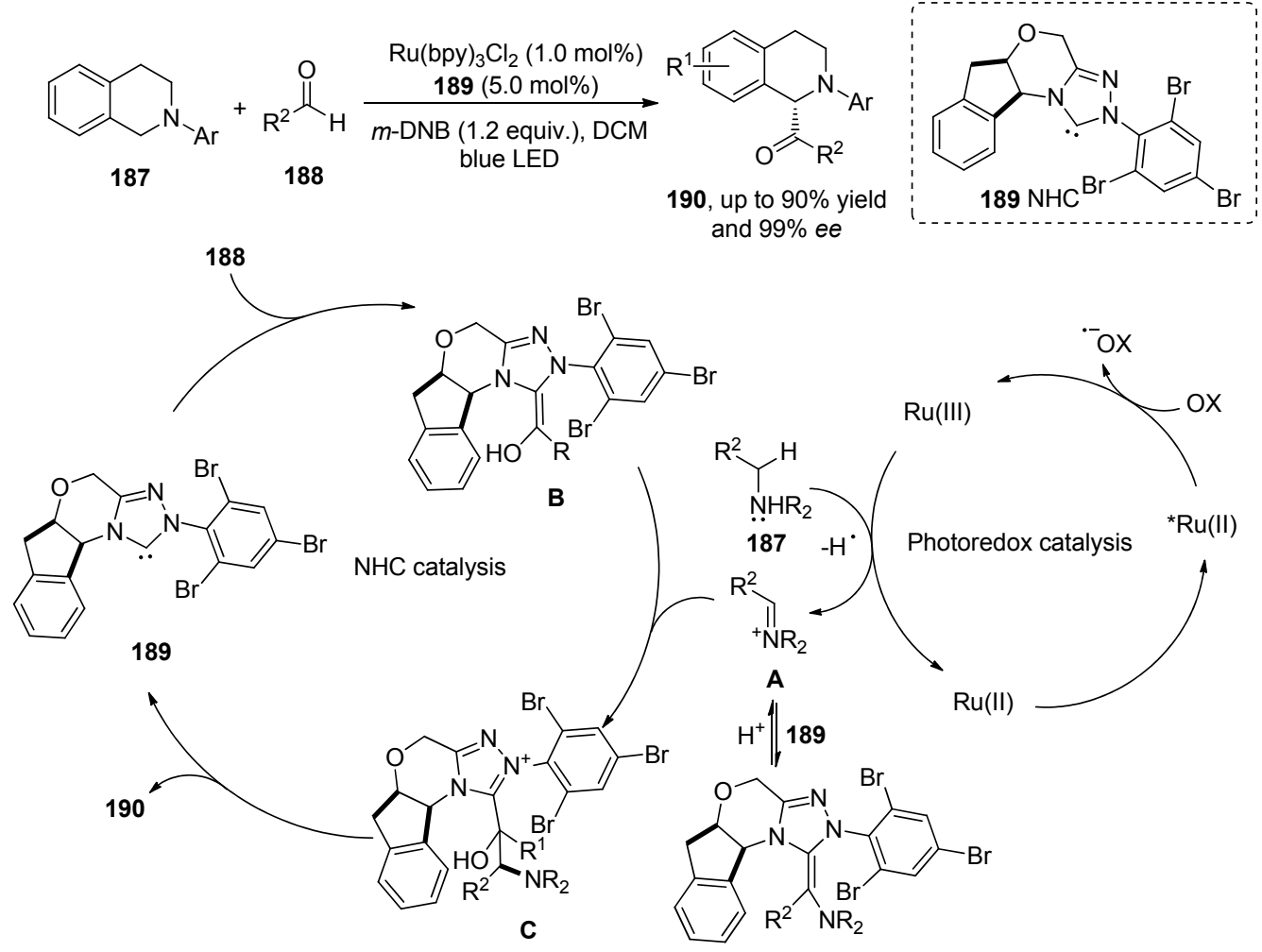

图式 39 胺的不对称 $\alpha$-酰化反应

Scheme 39 Asymmetric $\alpha$-acylation of amines 

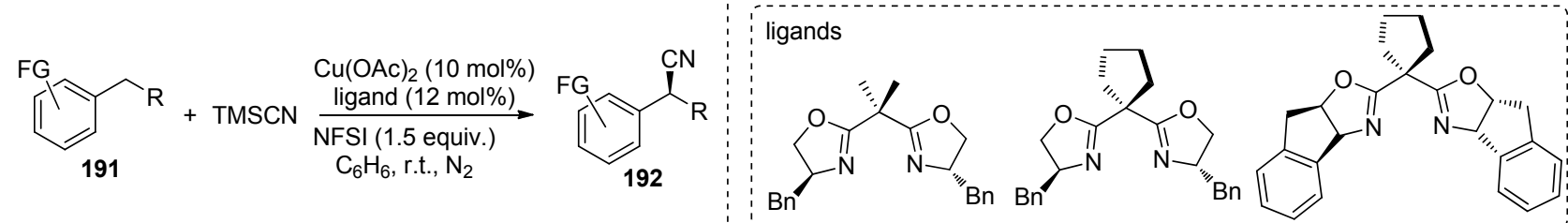

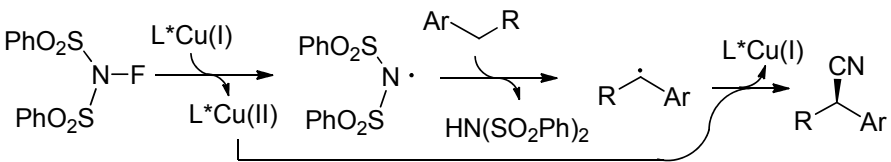<smiles>N#C[C@H](CO)c1cccc2ccccc12</smiles>

$87 \%, 92 \%$ ee<smiles>N#C[C@H](CN)c1cccc2ccccc12</smiles>

$73 \%, 97 \%$ ee<smiles>CCOc1ccc(C(C)C#N)c2ccccc12</smiles>

$91 \%,-99 \%$ ee<smiles>CC(C#N)c1ccc2c(c1)Cc1ccccc1-2</smiles>

$58 \%, 88 \%$ ee<smiles>COc1ccc(C(C)C#N)cn1</smiles>

$59 \%, 90 \%$ ee $39 \%, 80 \%$ ee
$\left(\mathrm{PhO}_{2} \mathrm{~S}\right)_{2} \mathrm{~N}$<smiles>CC(C)OC(=O)Nc1cc(C(C)C)sc1Br</smiles>

$79 \%,-94 \%$ ee

图式 $40 \mathrm{Cu}$ 催化的苄基不对称氰基化反应

Scheme 40 Cu-catalyzed asymmetric cyanation of benzyl

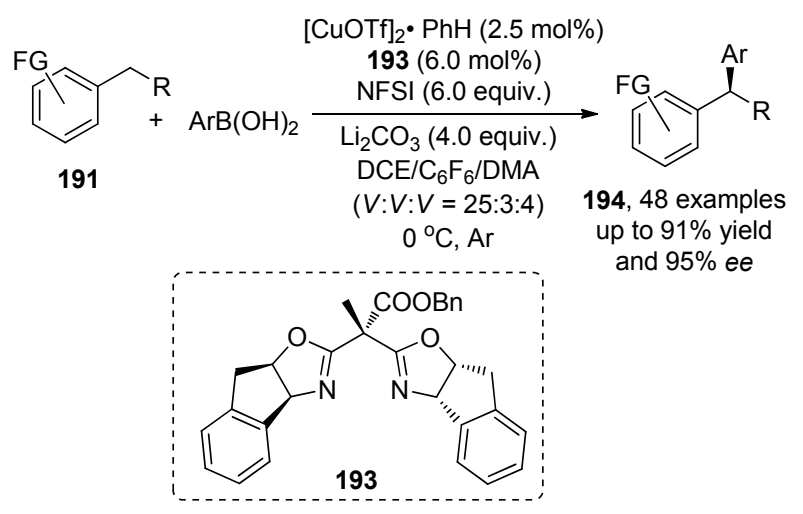

图式 41 苄基碳一氢键的不对称氧化偶联

Scheme 41 Asymmetric oxidative coupling of carbon-hydrogen bonds in benzyl
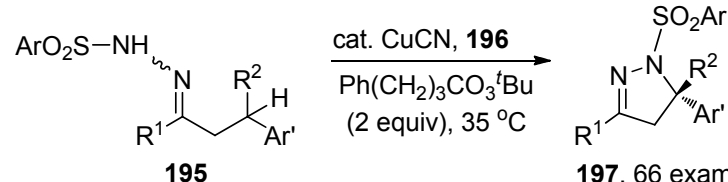

197, 66 examples up to $82 \%$ yield

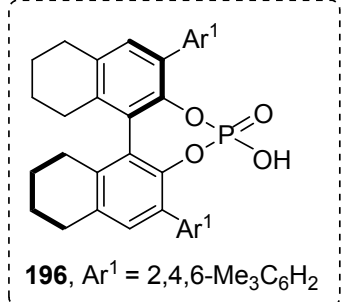
up to $96 \%$ ee

图式 42 分子内苄基 $\mathrm{C}-\mathrm{H}$ 的不对称氧化偶联 Scheme 42 Asymmetric oxidative coupling of intramolecular benzyl $\mathrm{C}-\mathrm{H}$

然后在手性磷酸协同作用下, 实现四元环醇的开环构建 目标螺环化合物 200 (Scheme 43).

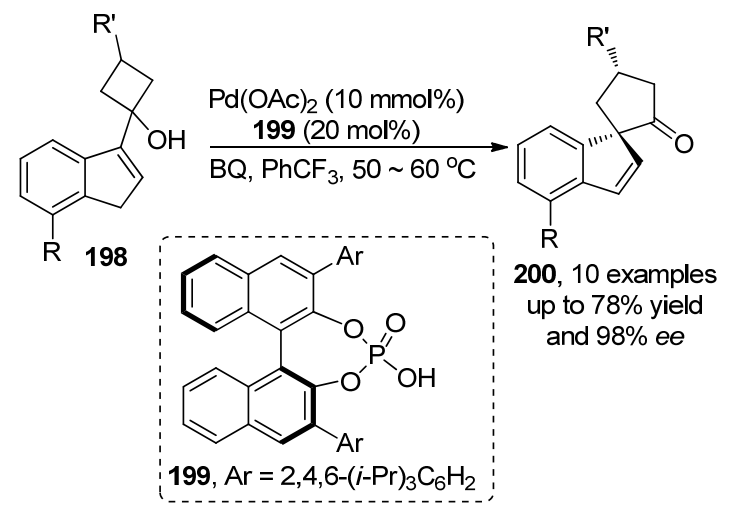

图式 $43 \mathrm{Pd}$ 催化的环丁醇的不对称氧化反应 Scheme 43 Pd-catalyzed asymmetric oxidation of cyclobutanol

2008 年, White 课题组 ${ }^{[70 a]}$ 报道了首例钯催化的末端 烯烃的不对称烯丙基碳氢键乙酰氧基化反应. 该方法中 使用双金属催化剂 $\mathrm{Pd}(\mathrm{SOX}) 202$ 和 $\mathrm{Gr}$ (Salen) 203, 手性 路易斯酸为助催化剂, 实现了烯丙基的 $\mathrm{C}-\mathrm{H}$ 键不对称 氧化反应(Scheme 44, a). Pd 和 SOX 配体络合的催化剂, 在实现反应的对映选择性方面最为成功，是烯丙基 $\mathrm{C}-$ $\mathrm{H}$ 键不对称氧化反应的一种有效合成策略 ${ }^{[70]}$. 该方法的 立体选择性控制是通过手性路易斯酸与有机金属中间 体相互作用的中间过程实现，这一点在不加入手性路易 斯酸或者加入无手性路易斯酸控制实验中，其产物的对 映选择性变化情况得到证实. 随后借助此类催化剂, 他 们发展了活泼亚甲基类型的底物与烯丙基的不对称氧 化偶联反应. 利用 $\operatorname{Pd}(\mathrm{SOX})$ 络合物催化剂, 实现了烯丙 基 $\mathrm{C}-\mathrm{H}$ 不对称胺化，反应具有较好的反应效果. 该方 法中改变亚砜配体的取代基和改变氧化剂结构, 能够控 制胺化产物的构型. 产生该现象的原因是氧化剂参与反 
应中间体的形成, 改变了两者的取代基, 影响中间体的 空间取向, 从而改变最终产物构型. 该方法能够实现手 性五元和六元的产物的合成, 且具有良好的对映选择性 和产率, 其产物能够应用于多取代官能团的手性 1,2-氨 基醇的合成(Scheme 44).

2018 年, 我们课题组 ${ }^{[71]}$ 报道了 $\mathrm{UiO}$ 型手性锆-金属 硅铝构建的金属有机骨架化合物(MOFs)催化剂, 实现 了苄基碳的不对称叠氮化反应. 该方法通过 $\mathrm{Zr}_{6} \mathrm{O}_{8}$ 团簇 组成的封闭手性笼与金属盐络合，这是控制产物对映选
择性的关键. 2019, 刘国生课题组 ${ }^{[72]}$ 在其前期研究基础 上，发展了烯丙基碳氢键的不对称氧化氰基化反应. 该 方法中 $\mathrm{N}-\mathrm{F}$ 氧化剂与铜催化剂的络合物决定着烯丙基 区域选择性. 接着手性铜络合物发生迁移插入(该过程 是产物的对映选择性的提高的关键), 最后发生还原消 除得到目标产物 213. 底物实验中, 一些特殊的官能团 化烯烃(烯基三氟甲磺酸酯和烯基硼等)也能够得到较好 的反应结果，这些官能团为产物的其进一步官能团化提 供了可能(Scheme 45).

(a)

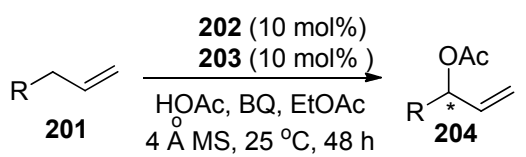

(b)
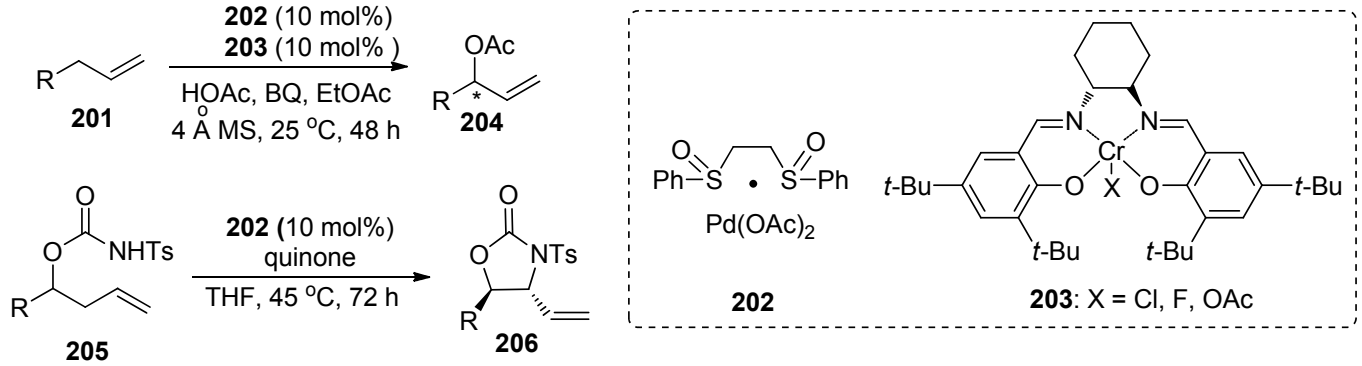

(c)

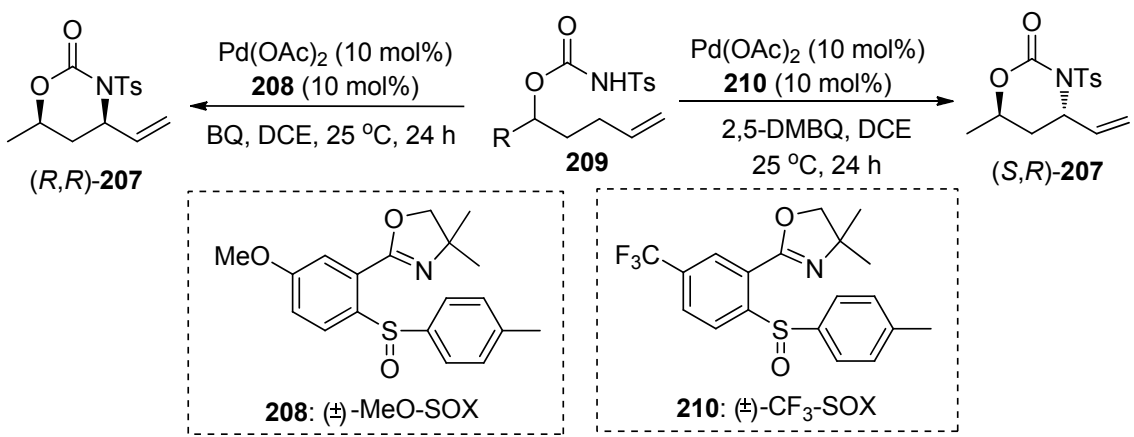

图式 $44 \mathrm{Pd}$ 催化烯丙基的不对称氧化反应

Scheme 44 Pd-catalyzed asymmetric oxidation of allyl $\mathrm{C}-\mathrm{H}$
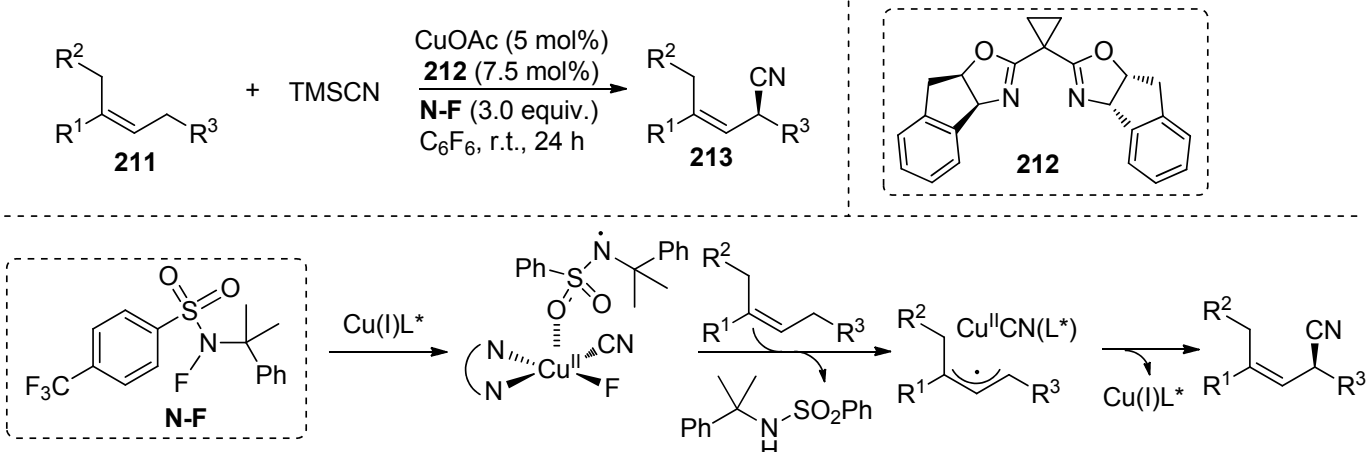

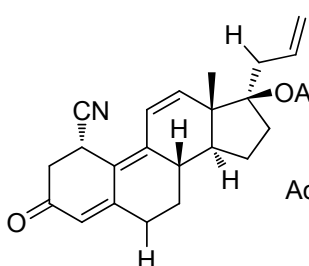

$65 \%, 99 \%$ de<smiles>C#C[C@]1(OC(C)=O)CC[C@H]2[C@@H]3C[C@H](C#N)C4=C[C@H](OC(C)=O)CC[C@H]4[C@H]3CC[C@]21C</smiles>

$60 \%(1.2 \mathrm{~g}), d r>20: 1$

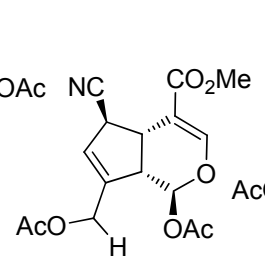

$63 \%, d r>20: 1$<smiles>CC(=O)O[C@H]1/C=C/C(=O)O[C@H](C)CC[C@H](C#N)/C=C\[C@H]2C[C@H](C)C[C@H]21</smiles>

$61 \%, d r>20: 1$

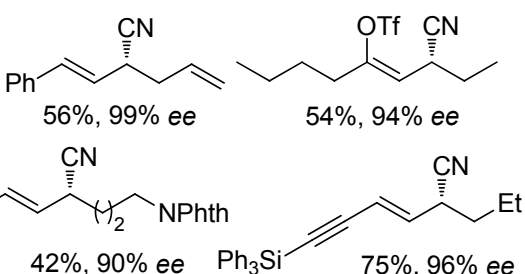

图式 $45 \mathrm{Cu}$ 催化的烯丙基不对称㲵基化反应

Scheme $45 \mathrm{Cu}$-catalyzed asymmetric cyanation of allyl 
2018 年, Bäckvall 等 ${ }^{[73]}$ 报道了在催化剂醋酸钯和氧 化剂苯醌的作用下, 实现烯醇分子内的不对称氧化反 应. 该方法中, 对于含氧基团(酮、醇盐、乙酸盐)均可以 实现环化反应生成环已烯 $\mathbf{2 1 5}$, 该反应关键在于含氧基 团与催化剂的络合作用, 通过含氧基团完成催化剂对双 键的迁移插入得到烷基钯物种, 此过程烯烃双键的面选 择性配位是实现羟基的非对映选择性的关键. 最后与硼 酸酯发生系列转化得到目标产物. 值得注意的是含氧官 能团的配位作用对于反应的发生是必要的，除去该官能 团则反应就不发生(Scheme 46).

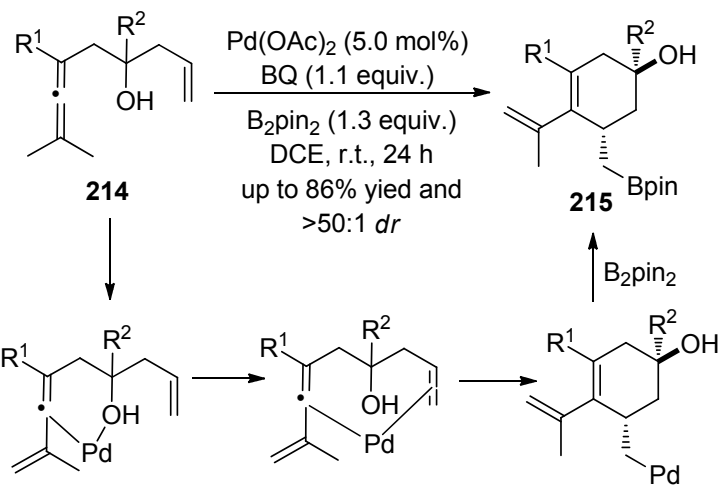

图式 46 烯烃分子内串联氧化反应

Scheme 46 Intramolecular cascade oxidation of olefins

\section{3 不对称 Baeyer-Villiger(BV)氧化反应和硫 醚不对称氧化反应}

\section{1 不对称 BV 氧化反应}

BV 氧化反应是由酮类合成酯或内酯的一种氧化方 法. 通过不对称 BV 氧化反应获得的手性内酯在药物合 成和天然产物合成具有重要的应用价值 ${ }^{[74]}$.

1994 年, Bolm 等 ${ }^{[75]}$ 报道以铜络合物 217 为催化剂, 实现了 2-取代环戊酮和环己酮等环酮类 $\mathbf{2 1 6}$ 的不对称 BV 氧化反应, 环己酮类底物相比环戊酮类底物表现出了更 好的反应效果(Scheme 47). 该方法的不足之处是产率和 对映选择性不太理想(最高 53\%的收率和 $65 \% e e$ ).

在金属与配体络合物催化剂促进的不对称 BV 氧化 反应中, 对于 2-或 3-取代的已酮和 2-取代的环戊酮, 能 够较好地获得 BV 氧化产物; 对于二取代的环酮类化合 物, 只有一些特定的官能团(如羟基和卤原子)存在时能 够以较好的对映选择性得到目标产物, 其他取代基底物 反应效率很差 ${ }^{[76]}$; 而并环酮在反应条件下表现出极好 的对映选择性 ${ }^{[77]}$. 这些实验现象结果归结于环的特定 的空间取向, 有利于反应的发生. 2019 年, 冯小明课题 组 ${ }^{[78]}$ 基于前期研究, 利用 $\mathrm{Sc}$ 和 $N, N^{\prime}$-二氧化物络合的催 化剂, 实现了 3-取代外消旋环己酮的不对称 BV 氧化反 应. 该方法是一个动力学拆分的案例, 通过外消旋底物

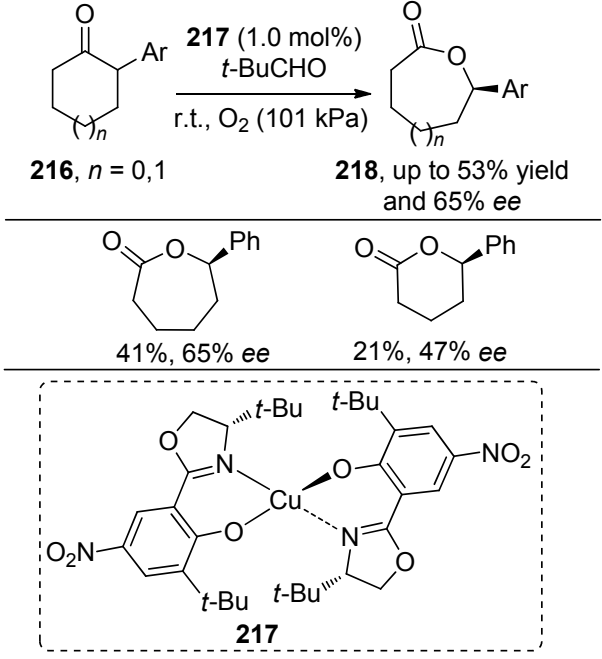

图式 $47 \mathrm{Cu}$ 催化手性环内酯合成

Scheme $47 \mathrm{Cu}$-catalyzed synthesis of chiral cyclic lactones

中单一构型参与 $\mathrm{BV}$ 氧化过程, 以较高的收率和拆分效 果得到手性 BV 氧化产物和 $S$ 构型的底物. 值得注意的 是通过改变配体骨架可以使 S-219 也发生 BV 氧化过程, 但也因此得不到单一构型的手性 BV 氧化产物. 底物实 验中，取代基团的基团效应对反应的对映选择性影响较 大， $\mathrm{R}$ 基为芳基和脂肪族取代基有利于产物对映选择性 的提高，同等条件下 $S$ 构型产物具有很好反应效果 (Scheme 48).

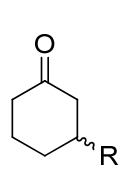

(土)-219
$\mathrm{Sc}(\mathrm{OTf})_{3}(5.0 \mathrm{~mol} \%)$ 220 (5.0 mol\%) $m$-CPBA ( 0.5 equiv.) $\mathrm{Al}\left(\mathrm{O}^{i} \mathrm{Pr}\right)_{3}(50 \mathrm{~mol} \%)$ $3 \AA \mathrm{MS}, \mathrm{EtOAC},-20^{\circ} \mathrm{C}$

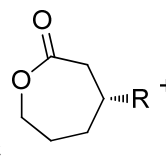

$(R)-221$<smiles>[R]C1CCCC(=O)OC1</smiles>

(S)-221

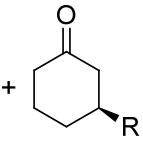

(S)-219
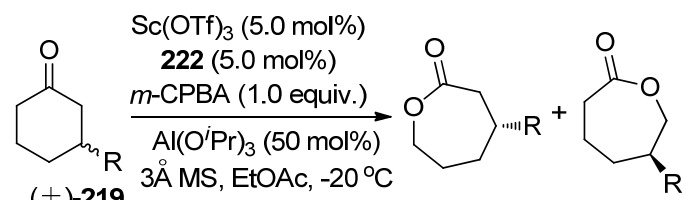

$( \pm)-219$

$(R)-221$

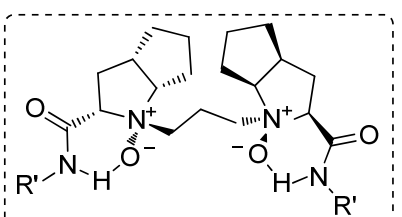

220, $\mathrm{R}=2,6-(i-\mathrm{Pr})_{2}-4-t-\mathrm{Bu}-\mathrm{C}_{6} \mathrm{H}_{2}$

222, $\mathrm{R}=2,6-\mathrm{Et}_{2} \mathrm{C}_{6} \mathrm{H}_{3}$

图式 $48 \mathrm{Sc}$ 催化的环己酮不对称 BV 氧化反应 Scheme 48 Sc-catalyzed asymmetric BV oxidation of cyclohexanone

在金属参与的不对称 BV 反应中，已经实现 2-或 3取代的环己酮和 2-取代的环戊酮的 BV 氧化产物高对映 选择性，不足的是 3-取代的环己酮底物无法得到单一构 
型的 BV 氧化产物; 再者是多取代的环酮类反应研究报 道比较少, 而且反应效果较差. 寻找新的合成策略解决 这些问题具有重要的研究意义.

\section{2 硫醚不对称氧化反应}

手性亚砜是天然产物和药物中普遍存在的结构单 元, 目前获得手性亚砜化合物的主要途径是亚砜化合物 的动力学拆分 ${ }^{\left[{ }^{[9]}\right.}$ 和硫醚化合物的不对称氧化反应.

芳基、脂肪以及长链取代的硫醚化合物的不对称氧 化反应研究报道中存在一些问题: 一是过度氧化产生副 产物砜, 导致主产物收率较低; 二是有些反应虽然产率 高, 但无法控制其对映选择性. Barman 等 ${ }^{[80]}$ 报道的金属 $\mathrm{Ti}$ 和配体络合的催化剂在实现硫醚不对称氧化反应中, 反应产物的收率极佳(均大于 $90 \%$ ), 但对映选择性比较 差(小于 $50 \% e e$ ). 目前解决方法是在反应体系中加入一 定量的添加剂. Tan 等 ${ }^{[81]}$ 报道了利用过氧钼酸盐 224 为 催化剂的硫梄类化合物 $\mathbf{2 2 3}$ 的不对称氧化反应. 他们在 反应体系中加入 0.5 equiv. 的 $\mathrm{KHSO}_{4}$, 能极大改善反应 的效果. 在底物实验中, 当 $\mathrm{R}^{2}$ 为吸电子基团、 $\mathrm{R}^{1}$ 为苄基 或者芳基时, 在标准反应条件下产率和对映选择性都极 好, 但是 $\mathrm{R}^{1}$ 为烷基时, 反应收率较高, 对映选择性却较 差(Scheme 49).

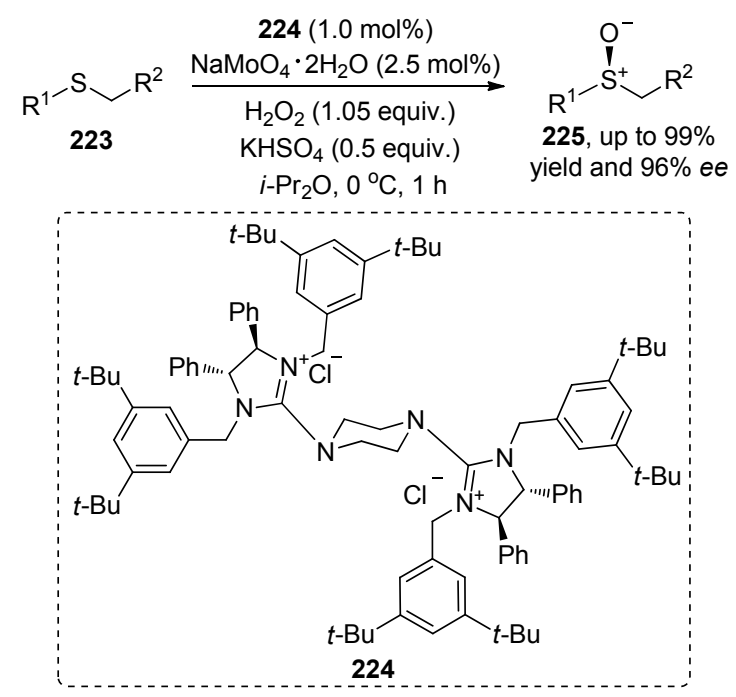

图式 49 钼酸盐催化的硫醚类化合物的不对称氧化反应

Scheme 49 Molybdate-catalyzed asymmetric oxidation of sulfide compounds

在众多反应的添加剂里, 羊酸作为添加剂的反应效 果较好 ${ }^{[79]}$. 在高爽课题组 ${ }^{[82]}$ 报道中, 以 $\mathrm{Mn}$ 和卟啉衍生 物络合物为催化剂, 以 1-金刚烷甲酸(aca)为添加剂, 实 现了芳基和芳香杂环硫化物 226 的不对称氧化反应. 该 反应在锰和配体络合物催化剂和 $\mathrm{H}_{2} \mathrm{O}_{2}$ 氧化剂作用下, 底物的反应快速, 高效地得到目标产物(芳基硫化物反 应需 $2 \mathrm{~h}$, 而杂环硫化物仅需 $0.5 \mathrm{~h}$ ). 该方法中, 改变配
体的骨架，高收率和高对映选择性地得到不同构型的产 物. 在底物实验中，不同的芳基底物以及 $\mathrm{R}^{1}$ 和 $\mathrm{R}^{2}$ 基团 的改变对反应的影响不大, 只有当芳基 $\mathrm{R}^{1}$ 的邻位为吸 电子基团时反应的对映选择性稍微降低. 对于环状硫化 物的反应, 也能很好地得到相应的目标产物, 芳香杂环 硫化物可以拓展至六元二氮、三氮杂环、五元噻吩、咪 唑和吡咯等化合物(Scheme 50).

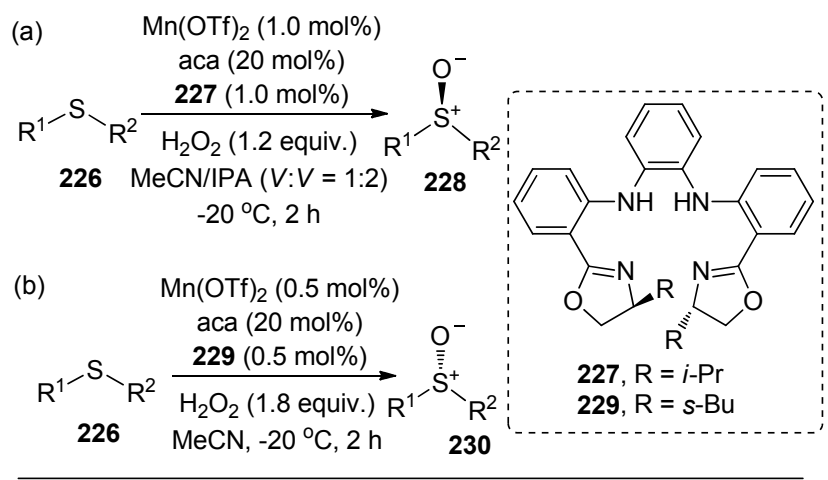<smiles>COC(=O)c1ccccc1[S+](C)[O-]</smiles>
$88 \%, 90 \%$ ee $\quad 95 \%, 80 \%$ ee<smiles>[O-][S+](c1ccccc1)c1ccccc1</smiles><smiles>O=C1c2ccccc2C[S+]([O-])c2ccccc21</smiles>

(b)<smiles>C[Si]([O-])c1cccc(C([O-])[18OH])n1</smiles>

图式 50 锰催化的硫化物不对称氧化反应

Scheme 50 Mn-catalyzed asymmetric oxidation of sulfide

\section{4 总结与展望}

近些年来，过渡金属催化的不对称氧化方法在烯烃 不对称环氧化反应、 $\mathrm{C}-\mathrm{H}$ 键不对称氧化反应、不对称 BV 氧化反应和硫醚不对称氧化反应等几个方面取得了 较大的发展, 有些方法为获取天然产物和药物分子提供 了简便高效的合成途径，在合成和应用上展示了重要价 值. 值得注意的是，伴随着资源高效利用和环境保护的 必然要求，金属参与的氧化反应正逐步迈向绿色、高效、 精准的新时代, 包括氧气、双氧水、内源氧化剂以及 MOFs 催化剂在内的新型氧化体系不断涌现, 日致成 熟 ${ }^{[83]}$. 从本文列举的研究实例中, 我们不难发现, 与新 型氧化体系对应的不对称氧化反应的实例依然不多. 展 望未来的发展, 要实现绿色、高效和精准的不对称氧化 反应，首先，与新型氧化体系匹配的手性配体和催化剂 的设计、制备是实现高对映选择性氧化反应中的关键; 其次, 引入光化学等因素的共催化体系对于发展新型不 
对称氧化反应具有重要的作用; 最后, 实现不对称氧化 反应在天然产物和药物分子合成中的应用是必然要求.

\section{References}

[1] (a) Saisaha, P.; de Boerb, J. W.; Browne, W. R. Chem. Soc. Rev. 2013, 42, 2059.

(b) Zhu, Y.; Wang, Q.; Cornwall, R. G.; Shi, Y. Chem. Rev. 2014, 114,8199 .

(c) Liu, C.; Wen, K.-G.; Zeng, X.-P.; Peng, Y.-Y. Adv. Synth. Catal. 2020, 362, 1015.

(f) Bryliakov, K. P. Chem. Rev. 2017, 117, 11406.

[2] Katsuki, T.; Sharpless, K. B. J. Am. Chem. Soc. 1980, 102, 5974.

[3] (a) Zhang, W.; Loebach, J. L.; Wilson, S. R.; Jacobsen, E. N. J. Am. Chem. Soc. 1990, 112, 2801.

(b) Irie, R.; Noda, K.; Ito, Y.; Matusumoto, N.: Katsuki, T. Tetrahedron Lett. 1990, 31, 7345.

[4] Jacobsen, E. N.; Markó, I.; Mungall, W. S.; Schroder, G.; Sharpless, K. B. J. Am. Chem. Soc. 1988, 110, 1968.

(b) Li, G.; Chang, H. T.; Sharpless, K. B. Angew. Chem., Int. Ed. 1996, 35,451

[5] Ji, N.; Yuan, J.; Liu, M.; Lan, T.; He, W. Chem. Commun. 2016, 52, 7731 .

[6] Wang, C.; Yamamoto, H. J. Am. Chem. Soc. 2014, 136, 1222.

[7] Bhadra, S.; Akakura, M.; Yamamoto, H. J. Am. Chem. Soc. 2015, 137,15612

[8] (a) Chu, Y.; Liu, X.; Li, W.; Hu, X.; Lin, L.; Feng, X. Chem. Sci. 2012, 3, 1996

(b) Chu, Y.; Hao, X.; Lin, L.; Chen, W.; Li, W.; Tan, F.; Liu, X.; Feng, X. Adv. Synth. Catal. 2014, 356, 2214.

[9] Clarasó, C.; Vicens, L.; Polo, A.; Costas, M. Org. Lett. 2019, 21, 2430.

[10] Zhang, W.; Jacobsen, E. N. J. Org. Chem. 1991, 56, 2296.

[11] Koya, S.; Nishioka, Y.; Mizoguchi, H.; Uchida, T.; Katsuki, T. Angew. Chem., Int. Ed. 2012, 51, 8243 .

[12] Kobayashi, Y.; Obayashi, R.; Watanabe, Y.; Miyazaki, H.; Miyata, I.; Suzuki, Y.; Yoshida, Y.; Shioiri, T.; Matsugi, M. Eur. J. Org. Chem. 2019, 2019, 2401.

[13] Farokhi, A.; Berijani, K.; Hosseini-Monfared, H. Catal. Lett. 2018, $148,2608$.

[14] Jat, J. L.; De, S. R.; Kumar, G.; Adebesin, A. M.; Gandham, S. K.; Falck, J. R. Org. Lett. 2015, 17, 1058.

[15] Zhu, H.; Chen, P.; Liu, G. J. Am. Chem. Soc. 2014, 136, 1766.

[16] Qi, X.; Chen, C.; Hou, C.; Fu, L.; Chen, P.; Liu, G. J. Am. Chem. Soc. 2018, 140, 7415

[17] (a) Sherman, E. S.; Chemler, S. R.; Tan, T. B.; Gerlits, O. Org. Lett., 2004, 6, 1573 .

(b) Chemler, S. R.; Karyakarte, S. D.; Khoder, Z. M. J. Org. Chem. 2017, 82, 11311.

[18] Fu, S.; Yang, H.; Li, G.; Deng, Y.; Jiang, H.; Zeng, W. Org. Lett. 2015, 17, 1018

[19] Zhang, W.; Chen, P.; Liu, G. Angew. Chem., Int. Ed. 2017, 56, 5336.

[20] Bai, Z.; Zheng, S.; Bai, Z.; Song, F.; Wang, H.; Peng, Q.; Chen, G.; He, G. ACS Catal. 2019, 9, 6502.

[21] (a) Huang, L.; Wang, Q.; Liu, X.; Jiang, H. Angew. Chem., Int. Ed. 2012, 51, 5696.

(b) Zhang, Z.; Wu, W.; Liao, J.; Li, J.; Jiang, H. Chem.-Eur. J. 2015, 21, 6708 .

[22] (a) Wu, M.-S.; Fan, T.; Chen, S.-S.; Han, Z.-Y.; Gong, L.-Z. Org. Lett. 2018, 20, 2485

(b) Zhang, T.; Shen, H.-C.; Xu, J.-C.; Fan, T.; Han, Z.-Y.; Gong, L.-Z. Org. Lett. 2019, 21, 2048.

(c) Chen, S.-S.; Wu, M.-S.; Han, Z.-Y. Angew. Chem., Int. Ed. 2017, 56, 6641 .

[23] Zhang, G.; Fu, L.; Chen, P.; Zou, J.; Liu, G. Org. Lett. 2019, 21, 5015.

[24] Fu, N.; Song, L.; Liu, J.; Shen, Y.; Siu, J. C.; Lin, S. J. Am. Chem.
Soc. 2019, $141,14480$.

[25] Mikami, K.; Hatano, M.; Terada, M. Chem. Lett. 1999, 28, 55

[26] Schiffner, J. A.; Machotta, A. B.; Oestreich, M. Synlett 2008, 15, 2271.

[27] Zhang, C.; Santiago, C. B.; Crawford, J. M.; Sigman, M. S. J. Am. Chem. Soc. 2015, 137, 15668.

[28] Akiyama, K.; Wakabayashi, K.; Mikami, K. Adv. Synth. Catal. 2005, 347, 1569

[29] Yoo, K. S.; Park, C. P.; Yoon, C. H.; Sakaguchi, S.; O'Neill, J.; Jung, K. W. Org. Lett. 2007, 9, 3933.

[30] Chen, G.; Cao, J.; Wang, Q.; Zhu, J. Org. Lett. 2020, 22, 322.

[31] (a) Walker, S. E.; Lamb, C. J. C.; Beattie, N. A.; Nikodemiak, P.; Lee, A.-L. Chem. Commun. 2015, 51, 4089. (b) Lamb, C. J. C.; Vilela, F.; Lee, A.-L. Org. Lett. 2019, 21, 8689

[32] (a) Mei, T.; Patel, H.; Sigman, M. S. Nature 2014, 508, 340. (b) Chen, Z.-M.; Hilton, M. J.; Sigman, M. S. J. Am. Chem. Soc. 2016, 138, 11461.

[33] (a) Shi, B. F.; Zhang, Y. H.; Lam, J. K.; Wang, D. H.; Yu, J. Q. J. Am. Chem. Soc. 2010, 132, 460.

(b) Xiao, K.-J.; Chu, L.; Yu, J.-Q. Angew. Chem., Int. Ed. 2016, 55, 2856.

[34] (a) Pi, C.; Li, Y.; Cui, X. L.; Zhang, H.; Han, Y. B.; Wu, Y. J. Chem. Sci. 2013, 4, 2675.

(b) Huang, Y.; Pi, C.; Cui, X.; Wu, Y. Adv. Synth. Catal. 2020, 362, 1385.

[35] Zheng, J.; Cui, W.-J.; Zheng, C.; You, S.-L. J. Am. Chem. Soc. 2016, $138,5242$.

[36] McDonald, R. I.; White, P. B.; Weinstein, A. B.; Tam, C. P.; Stahl, S. S. Org. Lett. 2011, 13, 2830.

[37] (a) Yip, K.-T.; Yang, M.; Law, K.-L.; Zhu, N.-Y.; Yang, D. J. Am. Chem. Soc. 2006, 128, 3130.

(b) He, W.; Yip, K.-T.; Zhu, N.-Y.; Yang, D. Org. Lett. 2009, 11, 5626 .

(c) Du, W.; Gu, Q.; Li, Y.; Lin, Z.; Yang, D. Org. Lett. 2017, 19, 316.

[38] Bao, X.; Wang, Q.; Zhu, J. Angew. Chem., Int. Ed. 2018, 57, 1995.

[39] Kou, X.; Shao, Q.; Ye, C.; Yang, G.; Zhang, W. J. Am. Chem. Soc. 2018, 140, 7587.

[40] Sen, A.; Takenaka, K.; Sasai, H. Org. Lett. 2018, 20, 6827.

[41] Allen, J. R.; Bahamonde, A.; Furukawa, Y.; Sigman, M. S. J. Am. Chem. Soc. 2019, 141, 8670.

[42] (a) Davies, H. M. L.; Beckwith, R. E. J. Chem. Rev. 2003, 103, 2861.

(b) Giri, R.; Shi, B.-F.; Engle, K. M.; Maugel, N.; Yu, J. Q. Chem. Soc. Rev. 2009, 38, 3242

(c) Liao, K.; Negretti, S.; Musaev, D. G.; Bacsa, J.; Davies, H. M. L. Nature 2016, 533, 230 .

(d) Wu, Q.-F.; Shen, P.-X.; He, J.; Wang, X.-B.; Zhang, F.; Shao, Q.; Zhu, R.-Y.; Mapelli, C.; Qiao, J. X.; Poss, M. A.; Yu, J.-Q. Science 2017, 355, 499.

[43] (a) Meunier, B.; de Visser, S. P.; Shaik, S. Chem. Rev. 2004, 104, 3947.

(b) Butler, A.; Sandy, M. Nature 2009, 460, 848 .

[44] Milan, M.; Bietti, M.; Costas, M. ACS Cent. Sci. 2017, 3, 196. (b) Sun, W.; Sun, Q. Acc. Chem. Rev. 2019, 52, 2370.

[45] Shi, B. F.; Maugel, N.; Zhang, Y. H.; Yu, J. Q. Angew. Chem., Int. Ed. 2008, 47, 4882 .

[46] Xiao, K.-J.; Chu, L.; Chen, G.; Yu, J.-Q. J. Am. Chem. Soc. 2016 $138,7796$.

[47] Cheng, X. F.; Li, Y.; Su, Y. M.; Yin, F.; Wang, J. Y.; Sheng, J.; Vora, H. U.; Wang, X. S.; Yu, J. Q. J. Am. Chem. Soc. 2013, 135, 1236.

[48] Du, Z. J.; Guan, J.; Wu, G. J.; Xu, P.; Gao, L. X.; Han, F. S. J. Am. Chem. Soc. 2015, 137, 632.

[49] Zhang, H.-H.; Wang, C.-S.; Li, C.; Mei, G.-J.; Li, Y.; Shi, F. Angew. Chem., Int. Ed. 2017, 56, 116.

[50] He, Y.-P.; Wu, H.; Wang, Q.; Zhu, J. Angew. Chem., Int. Ed. 2020 , $59,2105$.

[51] Tian, M.; Bai, D.; Zheng, G.; Chang, J.; Li, X. J. Am. Chem. Soc. 
2019, 141, 9527.

[52] (a) Gao, D. W.; Shi, Y. C.; Gu, Q.; Zhao, Z. L.; You, S. L. J. Am. Chem. Soc. 2013, 135, 86

(b) Shi, Y. C.; Yang, R. F.; Gao, D. W.; You, S. L. Beilstein J. Org. Chem. 2013, 9, 1891.

[53] Zhang, H.; Cui, X. L.; Yao, X. N.; Wang, H.; Zhang, J. Y.; Wu, Y. J. Org. Lett. 2012, 14, 3012

[54] (a) Gao, D.-W.; Gu, Q.; You, S.-L. J. Am. Chem. Soc. 2016, 138, 2544.

(b) Cai, Z.-J.; Liu, C.-X.; Gu, Q.; Zheng, C.; You, S.-L. Angew. Chem., Int. Ed. 2019, 58, 2149.

[55] Wang, S.-G.; Liu, Y.; Cramer, N. Angew. Chem., Int. Ed. 2019, 58, 18136.

[56] Wasa, M.; Engle, K. M.; Lin, D. W.; Yoo, E. J.; Yu, J. Q. J. Am. Chem. Soc. 2011, 133, 19598.

[57] Xiao, K. J.; Lin, D. W.; Miura, M.; Zhu, R. Y.; Gong, W.; Wasa, M.; Yu, J. Q. J. Am. Chem. Soc. 2014, 136, 8138.

[58] Hu, L.; Shen, P.-X.; Shao, Q.; Hong, K.; Qiao, J. X.; Yu, J.-Q. Angew. Chem., Int. Ed. 2019, 58, 2134.

[59] Yin, C.; Cao, W.; Lin, L.; Liu, X.; Feng, X. Adv. Synth. Catal. 2013, 355, 1924.

[60] Yang, F.; Zhao, J.; Tang, X.; Zhou, G.; Song, W.; Meng, Q. Org. Lett. 2017, 19, 448.

[61] Ding, W.; Lu, L.-Q.; Zhou, Q.-Q.; Wei, Y.; Chen, J.-R.; Xiao, W.-J. J. Am. Chem. Soc. 2017, 139, 63.

[62] Yang, F.; Zhao, J.; Tang, X.; Wu, Y.; Yu, Z.; Meng, Q. Adv. Synth. Catal. 2019, 361, 1673.

[63] Banerjee, A.; Yamamoto, H. Org. Lett. 2017, 19, 4363.

[64] DiRocco, D. A.; Rovis, T. J. Am. Chem. Soc. 2012, 134, 8094.

[65] Kharasch, M. S.; Sosnovsky, G. J. Am. Chem. Soc. 1958, 80, 756.

[66] Zhang, W.; Wang, F.; McCann, S. D.; Wang, D.; Chen, P.; Stahl, S. S.; Liu, G. Science 2016, 353, 1014

[67] Zhang, W.; Wu, L.; Chen, P.; Liu, G. Angew. Chem., Int. Ed. 2019, 58,6425 .

[68] Yang, C.; Zhang, C.; Gu, Q.-S.; Fang, J.-H.; Su, X.-L.; Ye, L.; Sun, Y.; Tian, Y.; Li, Z.-L.; Liu, X.-Y. Nat. Catal. 2020, 3, 539.

[69] Chai, Z.; Rainey, T. J. J. Am. Chem. Soc. 2012, 134, 3615.

[70] (a) Covell, D. J.; White, M. C. Angew. Chem., Int. Ed. 2008, 47, 6448 . (b) Liu, W.; Ali, S. Z.; Ammann, S. E.; White, M. C. J. Am. Chem. Soc. 2018, 140, 10658

(b) Fraunhoffer, K. J.; White, M. C. J. Am. Chem. Soc. 2007, 129, 7274 .

(c) Ma, R.; Young, J.; Promontorio, R.; Dannheim, F. M.; Pattillo, C. C.; White, M. C. J. Am. Chem. Soc. 2019, 141, 9468.

[71] Li, J.; Ren, Y.; Yue, C.; Fan, Y.; Qi, C.; Jiang, H. ACS Appl. Mater. Interfaces 2018, 10, 36047 .

[72] Li, J.; Zhang, Z.; Wu, L.; Zhang, W.; Chen, P.; Lin, Z.; Liu, G. Nature 2019, 574, 516 .

[73] Posevins, D.; Qiu, Y.; Bäckvall, J.-E. J. Am. Chem. Soc. 2018, 140, 3210.

[74] Zhou, L.; Liu, X.; Ji, J.; Zhang, Y.; Wu, W.; Liu, Y.; Lin, L.; Feng, X. Org. Lett. 2014, 16, 3938.

[75] Bolm, C.; Schlingloff, G.; Weickhardt, K. Angew. Chem., Int. Ed. 1994, 33, 1848.

[76] Lopp, M.; Paju, A.; Kanger, T.; Pehk, T. Tetrahedron Lett. 1996, 37, 7583.

[77] Bianchini, G.; Cavarzan, A.; Scarso, A.; Strukul, G. Green Chem. 2009, 11, 1517.

[78] Wu, W.; Cao, W.; Hu, L.; Su, Z.; Liu, X.; Feng, X. Chem. Sci. 2019, $10,7003$.

[79] Wang, L.; Chen, M.; Zhang, P.; Li, W.; Zhang J. J. Am. Chem. Soc. 2018, 140, 3467.

[80] Barman, S.; Patil, S.; Levy, C. J. Chem. Lett. 2012, 41, 974.

[81] Zong, L.; Wang, C.; Putra Moeljadi, A. M.; Ye, X.; Ganguly, R.; Li, Y.; Hirao, H.; Tan, C.-H. Nat. Commun. 2016, 7, 13455.

[82] (a) Dai, W.; Li, G.; Wang, L.; Chen, B.; Shang, S.; Lv, Y.; Gao, S. RSC Adv. 2014, 4, 46545.

(b) Dai, W.; Shang, S.; Lv, Y.; Li, G.; Li, C.; Gao, S. ACS Catal. 2017, 7, 4890.

[83] (a) Wu, W.; Jiang, H. Acc. Chem. Res. 2012, 45, 1736.

(b) Huang, H.; Ji, X.; Wu, W.; Jiang, H. Chem. Soc. Rev. 2015, 44, 1155.

(c) Liang, Y.; Jiao, N. Acc. Chem. Res. 2017, 50, 1640.

(d) Tang, X.; Wu, W.; Zeng, W.; Jiang, H. Acc. Chem. Res. 2018, 51,1092 .

(e) Li, J.; Liao, J.; Ren, Y.; Liu, C.; Yue, C.; Lu, J.; Jiang, H. Angew. Chem., Int. Ed. 2019, 58, 17148.

(Zhao, C.) 